\title{
Da oberst Paludan-Müller opsagde abonnementet
}

Flensborg Avis, nazismen og Abessinien-spørgsmålet 1935

\author{
af RENÉ RASMUSSEN
}

I 1930'ernes Senderjylland kunne debatten om diktaturstaterne og de totalitære ideologier antage ret skarpe former. Dette var også tilfældet i denne sag, der tog sit udgangspunkt i Mussolinis krav på det afrikanske land Abessinien - men som hurtigt udviklede sig til en principiel diskussion om Flensborg Avis' stilling til nationalsocialismen.

Cand.mag. René Rasmussen, Studieafdelingen og Arkivet ved Dansk Centralbibliotek for Sydslesvig, fortæller her om, hvordan sagen fik konsekvenser for dens to hovedpersoner: chefen for grænsegendarmeriet, oberst S. B. PaludanMüller, og chefredaktøren for Flensborg Avis, Ernst Christiansen. Sagen belyser sønderjyske synspunkter på nazismen - og illustrerer den danske regerings vagtsomhed, når det gjaldt om at opretholde et godt forhold til Europas stormagter.

Oberst Svend Bartholin Paludan-Müllers ensomme kamp i Gråsten den 26. maj 1944 er kendt af de fleste. Der er noget næsten mytologisk over Paludan-Müllers skæbne hin forårsdag: Tidligt om morgenen ankom Gestapo til hans bopæl for at tage ham ind til forhør. Han satte sig til modværge og forskansede sig i sin embedsbolig ved indgangen til Gråsten Slot. De følgende timer udkæmpede han ene mand imod næsten 40 tyske soldater og Gestapo-folk en ulige kamp, der først sluttede, da huset var omspændt af flammer og Paludan-Müller afgået ved døden. ${ }^{1}$

Dette er velkendt. Mindre kendt er måske, at Paludan-Müller i 1935 var tæt på at miste sin stilling som chef for grænsegendarmeriet efter kun ét år på posten. Ved sin offentlige stillingtagen til den italienske fremfærd i Abessinien gav han anledning til en tjenestemandssag imod sig selv - og til hårde angreb mod Flensborg Avis for at fremme nazismen i Sonderjylland. 


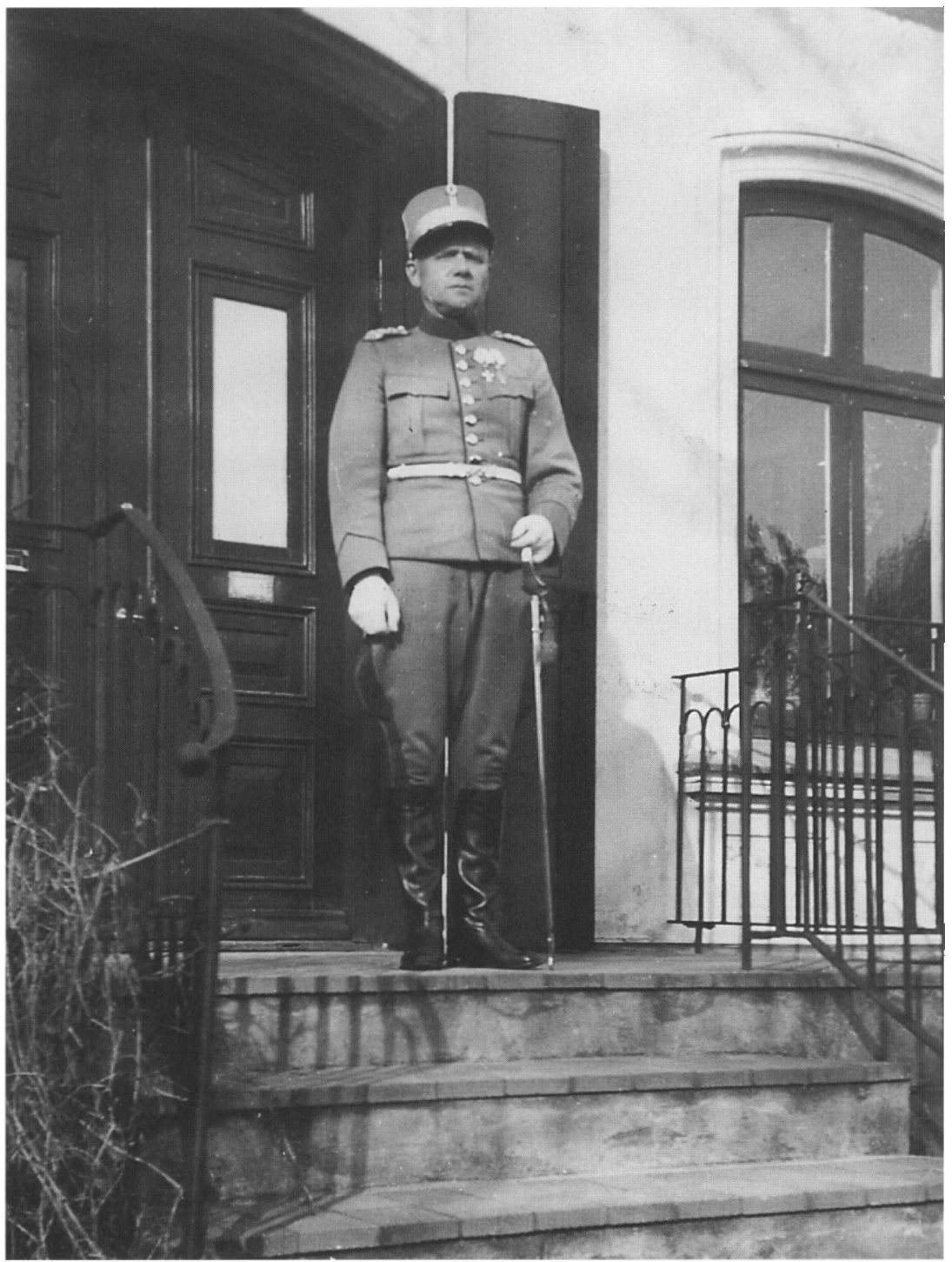

Svend Bartholin Paludan-Müller (1885-1944) fotograferet ved sin embedsbolig $i$ Gråsten. Fra 1904-1923 gjorde han karriere $i$ militæret. I 1923 udtrådte han efter 19 ar $i$ militæret af hærens linie og gik over til reserven. I 1930 blev han oberstløjtnant af reserven, og $i 1932$ overfort til forstærkningen. Næstkommanderende $i$ grænsegendarmeriet fra 1933 og året efter dets chef med bopæl $i$ Gråsten. Foto $i$ Institut for Sonderjysk Lokalhistorie. 


\section{Paludan-Müller}

S.B. Paludan-Müller var tiltrådt tjenesten den 5. januar 1933 som næstkommanderende. Da chefen for grænsegendarmeriet siden 1919, oberst Aage greve Moltke, året efter blev pensioneret, var PaludanMüller det naturlige valg som efterfølger, og han blev pr. 1. april 1934 den nye chef for grænsegendarmeriet, en post han bestred indtil sin død i 1944. S. B. Paludan-Müller var ved sin tiltræden 49 år gammel, gift på 24. år og far til tre børn. Han var en mand med de bedste anbefalinger. Hans regimentschef ved 8. regiment, oberst Wørishøffer, skrev $i$ en forholdsattest fra 1932 om ham, at han var viljestærk og energisk med en hurtig og klar opfattelsesevne og en usædvanlig sund dømmekraft; en mand med en fast og retlinet karakter, hvilket i forbindelse med en fremragende dygtighed gjorde ham til en betydelig personlighed, der i høj grad påvirkede dem, der stod under ham; han havde et lyst og ligevægtigt sind og et elskværdigt og taktfuldt væsen samt en djærv og frejdig optræden. Oberstløjtnanten havde i hele sin tjenestetid været et smukt eksempel for sine kammerater, og hans forhold såvel i som udenfor tjenesten havde i enhver henseende været mønsterværdige. ${ }^{2}$

Således var skudsmålet for den mand, der blev ny chef for grænsegendarmeriet. Han levede det følgende år til fulde op til Finansministeriets forventninger til en loyal og effektiv embedsmand - indtil han i 1935 tog ordet i en debat om den italienske fremfærd i Afrika.

\section{Abessinien-krisen 1935}

Op igennem 1930'erne havde Italien jævnligt skabt uroligheder på grænsen mellem Abessinien - omtrent det nuværende Etiopien - og de to italienske kolonier Somaliland og Eritrea. Italien, der under et forsøg på at erobre landet i 1896 havde lidt et forsmædeligt nederlag ved Adua, forsøgte nu under Benito Mussolini at gøre et nyt erobringsforsøg. Italien fremsatte i løbet af sommeren 1935 gentagne gange trusler, og Abessinien - en af de sidste selvstændige nationer $i$ et gennemkoloniseret Afrika - klagede sin nød til Folkeforbundet FN's mindre magtfulde forgænger -, der imidlertid ikke kunne stille meget op. Stormagterne Frankrig og England var ikke indstillede på at sætte hårdt imod hårdt af frygt for at støde Italien fra sig; de havde brug for Italien som forbundsfælle i forsøgene på at inddæmme Hit- 
lers ensidige nedbrydning af Versailles-traktaten. Mussolini havde da også ved det nazistiske kupforsøg i Østrig i juli 1934 stillet sig på vestmagternes side. Hitler havde måttet trakke sin støtte til kupmagerne tilbage, og kuppet var herefter slået fejl. Der var endnu i 1934 kold luft mellem Der Führer og Il Duce. Så sent som i april 1935 var de tre stormagter - England, Frankrig og Italien - ved et møde i byen Stresa blevet enige om at føre en fælles politik overfor Tyskland.

Da konflikten i Afrika mellem Italien og Abessinien i løbet af sommeren 1935 spidsede til, var man fra vestmagternes side nervøse for at føre en for fast politik over for Italien og derved støde landet over i armene på Tyskland, der jo uden smålige hensyn til Folkeforbund eller almindelig ret og rimelighed med lethed kunne overbyde vestmagternes indrømmelser over for Italien - og som også hurtigt indledte en charmeoffensiv over for den romerske diktator.

Der var endvidere grund til at tro, at situationen kunne udvikle sig til krig imellem Italien og England, der havde vitale interesser på Afrikas Horn. Freden i Europa var med andre ord voldsomt truet af konflikten i Afrika. ${ }^{3}$

\section{Flensborg Avis vurderer krisen}

Flensborg Avis, det sydslesvigske danske mindretals avis i Hitlers Tyskland, fulgte ligesom den øvrige danske og europæiske presse Abessinien-krisen med stor opmærksomhed og bekymring. Under krisens tilspidsning i sensommeren 1935 skrev Tage Jessen, avisens udenrigspolitiske redaktør, den 31. august $1935 \mathrm{i}$ avisens udenrigsoversigt, Verdens Gang, at krisen først og fremmest var et kolonispørgsmål; Italien var kommet senere i gang med koloniseringen end England og Frankrig, der begge havde vældige koloniområder i Afrika og Asien med både plads til udvidelse og masser af råstoffer. Det overbefolkede Italien trængte til begge dele, "og i Abessinien, hvis område er over dobbelt så stort som Italiens, hvis jord dels er frugtbar, dels bugner af naturrigdomme, er der plads til en betydelig overskudsbefolkning, der kan opdyrke jorden, udnytte råstofferne og civilisere landet«. Rubrikken blev afsluttet med nogle betragtninger om, hvorvidt kristendommen, kristelig tankegang og humane metoder $\mathrm{i}$ øvrigt bundede videre dybt $\mathrm{i}$ det abessinske kejserriges "virvar af mere eller mindre farvede stammer« - og at landet under alle omstændigheder bevisligt drev slaveri og slavehandel. Italiens hensigter 
over for Abessinien var altså - efter Tage Jessens mening - ikke slet så urimelige og uretfærdige endda.

Tage Jessen sluttede sin artikel med at foreslå følgende løsningsmodel, som han dog næppe havde gennemtænkt i sin fulde konsekvens: »Venner af fred mellem de europæiske stormagter kunne næsten føle sig fristede til at ønske et britisk mandat over Nord-Abessinien og en hurtig italiensk sejr over det øvrige Abessinien som den mest "smertefrie« afgørelse." Men en sådan hurtig afgørelse var der desværre ikke nogen udsigt til, så vidt Tage Jessen kunne se.

Det er her værd at lægge mærke til, at det var freden mellem de europæiske stormagter, der var Tage Jessens største bekymring og i hans fokus: Jessen foreslog med sine bemærkninger Abessinien ofret på den europæiske freds alter. Tankegangen var for så vidt nært beslægtet med »appeasement-politikken «, som Storbritannien slog ind på over for Tyskland $\mathrm{i}$ disse år, nemlig inden for visse grænser at forsøge at imødekomme Hitlers krav, indtil han var tilfreds - og derved undgå krigen. I praksis var Jessens tankeeksperiment heller ikke så fjernt fra det forslag, som udenrigsministrene for Storbritannien og Frankrig, Samuel Hoare og Pierre Laval, faktisk forsøgte at fremsætte i december 1935, da krigen var brudt ud, og som ville have tvunget Abessinien til store landafståelser. Dette forslag førte ganske vist også, som følge af den oprørte britiske opinion, til Hoares afgang.

Chefredaktør Ernst Christiansen lagde mundtligt straks over for Tage Jessen afstand til betragtningerne i den udenrigspolitiske artikel, men da var det imidlertid allerede for sent.

\section{Obersten opsiger abonnementet}

Oberst Paludan-Müller, der var en ivrig tilhænger af Folkeforbundstanken, havde fulgt udviklingen i Abessinien med bekymring; den italienske fremfærd bød ham inderligt imod, og han blev stærkt berørt over Folkeforbundets magtesløshed. Folkeforbundet var som bekendt blevet stiftet efter Første Verdenskrig med den klare målsætning at forhindre krig mellem nationerne, men nu så det ud til, at Folkeforbundet p.g.a. Italiens fuldstændige ringeagt over for alle forbundets indvendinger ville lide sit afgørende nederlag - til stor skade for opretholdelsen af freden mellem nationerne.

Der er ingen tvivl om, at Paludan-Müller har græmmet sig over udviklingen, og da han læste Flensborg Avis' forsvar for Mussolini, 
løb temperamentet af med ham. Samme dag, den 31. august 1935, opsagde han skriftligt grænsegendarmeriets abonnement på Flensborg Avis, da, som han skrev til chefredaktør Ernst Christiansen: "grænsegendarmeriet herefter betragter Flensborg Avis som et blad, man ikke kan være bekendt at holde. Bladet ønskes ikke for den resterende del af juli kvartal«. ${ }^{4}$ Brevet var affattet på grænsegendarmeriets officielle papir med journalnummer - A nr. 314 - og det hele; en detalje, der senere skulle vise sig at få betydning.

Ernst Christiansen blev hårdt ramt af oberstens brev. ${ }^{5}$ Han skrev samme dag i et brev til Paludan-Müller, at avisens linie som modstander af enhver erobringskrig naturligvis var urokket, og han foreslog en personlig samtale - til opklaring af den opståede misforståelse mellem Paludan-Müller og Tage Jessen. Jessen var ganske vist i mellemtiden taget på ferie, men et møde lod sig arrangere efter hans tilbagekomst. "Imidlertid mindes jeg ikke fra de 30 år, jeg har ledet Flensborg Avis, at bladet har været genstand for en sådan krænkelse i noget brev fra et tysk endsige da et dansk embedskontors side. Det er min pligt som dansk $i$ forpostlinien at give det svar, et blad med æresfølelse må give over for et sådant angreb, men jeg vil forinden dog indstille, at sagen bringes ud af verden ved, at det utilbørlige brev betragtes om uskrevet. ${ }^{6}$

Ernst Christiansen lod med andre ord Paludan-Müller forstå, at han forventede en undskyldning. Da var sagen imidlertid allerede brudt ud i offentligheden.

\section{Paludan-Müllers artikel}

Paludan-Müllers harme over udviklingen i Abessinien og over Flensborg Avis' stilling hertil havde efter alt at dømme ikke fået tilstrækkelig luft med opsigelsen af abonnementet. Han havde også sendt Aabenraa-avisen Hejmdal, der var Flensborg Avis' traditionelle konkurrent og politiske modstander i Sønderjylland, en længere redegørelse for sin opfattelse og sine bevæggrunde til at foretage et sådant skridt. Redegørelsen, der fyldte to spalter, blev trykt i Hejmdal den 3. september 1935 .

Stykket i Flensborg Avis havde - skrev Paludan-Müller i sit indlæg i sin Italiensk-venlighed været så utiltalende, at han straks havde opsagt abonnementet på bladet. »Harmen mod Italien er gennemgående alt for ringe i Danmark, men aldrig har jeg dog set retsbegreberne 
vendt således på hovedet som i den nævnte artikel i Flensborg Avis.« Mussolinis Italien var efter Paludan-Müllers mening en ren slyngelstat; han opregnede en række eksempler til belysning af "Italiens begreber om ret og ære«, bl.a. at Italien under 1 . verdenskrig havde vendt sig imod sin gamle allierede, Tyskland, da det i 1915 så, hvor det bar henad, og at Italien i 1923 grundløst havde angrebet Grækenland, og - for at hævde den italienske "ære" - havde bombarderet den fredelige $ø$ Korfu med talrige civile tab til følge. Den eneste årsag til den nuværende "konflikt« mellem Italien og Abessinien var, at "Italien uden skygge af ret ønsker at bemægtige sig Abessiniens rige territorium «, hvilket var i strid med alle indgåede internationale aftaler. Mussolini havde selv klart og kynisk erklæret, at han agtede at erobre Abessinien, fordi han havde brug for landet, skrev PaludanMüller harmdirrende.

At Flensborg Avis ved sin artikel også syntes at ville støtte tyske krav på tilbagelevering af de gamle afrikanske kolonier fra før 1918, som nu var under Englands protektion, kunne man mene om, hvad man ville, men derfor behøvede bladet ikke at støtte Italiens »voldsplaner mod Abessinien«. Paludan-Müller gik herefter i rette med konkrete udsagn fra Flensborg Avis' artikel: Overbefolkning gav ikke ret til at bemægtige sig andre lande, der havde bedre plads, og da slet ikke, når det overbefolkede land som Italien havde gjort det til en hellig pligt for landets kvinder at føde så mange børn - og helst drenge - som muligt. M.h.t. de påståede abessinske grusomheder vidste Flensborg Avis efter Paludan-Müllers mening ikke noget som helst, og der var i betragtning af Italiens folkeretlige moral sandelig ingen grund til at nære tiltro til det bevismateriale, Italien havde fremlagt. Men skulle det vise sig, at Abessinien rent faktisk havde begået grusomheder, gav dette ikke Italien nogen som helst ret til at erobre landet. Italien var, anførte Paludan-Müller, for øvrigt ikke et hår bedre, men havde behandlet de ulykkelige arabere i sine kolonier i Nordafrika (Libyen) mindst lige så slemt: De var blevet hængt, blot fordi de havde tilladt sig at forsvare deres fædrene jord. "Mon ikke italienernes og abessiniernes mentalitet karakteriseres af deres førere, ved Mussolinis pralende trusler og foragt for højtidelige løfter og international moral, og ved kejser Haile Selassies rolige og værdige appel til folkeforbundets samvittighed, en appel, som indtil nu er ubesvaret", fandt Paludan-Müller.

Flensborg Avis havde sluttet sin "ædle vejledning i folkeret« med at 
udtrykke det håb, at »Italien og England kunne blive enige om at dele Abessinien, og at Italien derefter i en fart kunne få held til at udrydde "sine« abessinierne med maskingevær og giftgas, idet der ikke skulle være grund til at være rørt over de værgeløse abessiniere eller harmfuld på det krigslystne Italien“, skrev Paludan-Müller med ætsende ironi, og fortsatte: "Disse betragtninger kalder jeg lave, rå og hjerteløse. Nej, Flensborg Avis, der er andre forhåbninger, som mennesker med retfærdighedsfølelse og æresbegreberne $\mathrm{i}$ orden må hengive sig til: At Folkeforbundet med alle lovlige midler vil lægge pres på voldsmanden og ikke som hidtil på offeret, og at Danmark herunder vil regne det for en ære at bære de byrder, der følger med at være medlem af folkenes forbund, og hvis krigen dog kommer, at da febersygdomme, sværd, spyd og de svigtede abessinieres alt for få riffelkugler må tilintetgøre den grådige græshoppesværm, der vælter ind over Abessiniens grænser.«

Denne - må man vel nok sige - grausame Salbe var undertegnet: S. B. Paludan-Müller - med tilføjelsen: Chef for Grænsegendarmeriet. Dette sidste skulle vise sig at blive fatalt.

\section{Flensborg Avis reagerer}

Allerede samme dag, den 3. september 1935 - for han havde fået kendskab til artiklen i Hejmdal, havde redaktør Ernst Christiansen forsøgt at minimere skaderne af Tage Jessens udenrigsoversigt ved at tage spørgsmålet om »overbefolkning og krig « op i en ledende artikel. Her slog han til en begyndelse fast, at et blad, der tog sin gerning alvorligt, måtte søge at belyse aktuelle spørgsmål fra alle sider. Det havde i Abessinien-spørgsmålet vist sig, at ingen af parterne var engle, hverken de to umiddelbare modstandere eller de ovrige stormagter, mente Ernst Christiansen.

Men det danske standpunkt måtte naturligvis altid være bandlysning af enhver erobringskrig. En erobringskrig blev ikke forsvarlig, blot fordi den blev bygget på, at det ene land var overbefolket og det andet tyndt befolket, eller at det ene land var nået videre i almindelig oplysning end det andet. Et modsat standpunkt ville efter Ernst Christiansens mening også have frygtelige konsekvenser. F.eks. hvis Tysklands befolkning - som det var dens regerings udtrykte plan - skulle vokse stærkt.

Ernst Christiansens fokus flyttede sig fra en - set fra Sydslesvig - 
forholdsvis inferiør stat i Afrika til princippets overførsel til Europa: Her ville det samme princip have skræmmende perspektiver over for de tyndt befolkede nordiske lande, og Ernst Christiansen afviste da også princippet blankt - og hermed betragtede han formentlig Tage Jessens uheldige bemærkninger i udenrigsoversigten som værende kaldt tilbage.

Men dermed var sagen dog langtfra afsluttet. Samme dag, den 3. september 1935, blev Paludan-Müllers udførlige artikel om Flensborg Avis, Italien og Abessinien trykt i Hejmdal, der sidst på dagen nåede til Flensborg. I sin dagbog noterede Ernst Christiansen sig: »Aften. Hejmdal med Paludan-Müllers artikel mod os, vred, dog rolig. « ${ }^{7}$ Han så sig nu forpligtet til at svare obersten offentligt.

Den følgende dags ledende artikel i Flensborg Avis beskæftigede sig med emnet: krigstruslen i verden. Ernst Christiansen udtrykte her det standpunkt, at det måske i virkeligheden var godt, at Folkeforbundets magtesløshed nu blev afsløret, thi Folkeforbundet fik nemlig næppe nogen sinde reel magt, før dets magtesløshed og den skæbnesvangre betydning heraf blev erkendt - og stormagterne handlede derefter ved at styrke Folkeforbundet. Folkeforbundets svaghed skyldtes efter Ernst Christiansens mening, at der udover elskværdige forsikringer og betænkninger ikke var rejst nogen »hensynsløs fælles vilje til at trygge fredens sag«. Fredsviljen var af gode grunde stærkest blandt de små nationer, men de holdt sig af de samme gode grunde tilbage med at give deres holdning udtryk $i$ handling. Og intet af de store lande havde villet tilsidesætte sine egne tarv så meget for den fælles freds skyld, at man kunne tale om, at der var gjort et virkeligt offer, der kunne tjene som eksempel til efterfolgelse.

Den virkeligt store vinding $\mathrm{i}$ en hvilken som helst sag - og altså også i fredens - blev ikke vundet ved halvhed eller ord alene; den krævede efter Ernst Christiansens opfattelse det store offer. Hvis hele nationen ofrede sig fuldt ud, ville man også nå sine mål. Denne forestilling om offerviljen som ideal var temmelig sikkert også den væsentligste grund til hans fascination af den tyske nationalsocialisme $i$ første halvdel af 1930'erne.

I den aktuelle situation i Afrika var det efter alt at dømme Ernst Christiansens mening, at kolonimagten England med sine store og rige besiddelser måtte være villig til at bringe et offer - f.eks. at afstå en bid af den afrikanske kage til Italien. ${ }^{8}$

Dette var Ernst Christiansens bud på en løsning på konflikten i 
Østafrika - der jo unægtelig stadig var langt fra Paludan-Müllers. Ernst Christiansen var tydeligvis både rystet $\mathrm{og}$ bitter over reaktionen fra grænsegendarmeriets side - og han forstod den formentlig slet ikke. For ham var det en indlysende national opgave for alle danske at bistå Flensborg Avis med forsvaret for danskheden i grænselandet og at overlade det til avisen selv at vælge den kampform, den fandt mest anvendelig.

Men dette var navnlig de danske socialdemokrater ikke indstillet på.

\section{Sønderborg Socialdemokrat intervenerer}

Sønderborg Socialdemokrat gav nemlig samme dag, den 4. september 1935, netop udtryk for en sådan for Ernst Christiansen vanskeligt forståelig holdning. Man gengav med overskriften En salve til Flensborg Avis Paludan-Müllers abonnementsopsigelse - og tilføjede: Det er »jo unægtelig en voldsom opsang, og måske kan det siges at være lidt pågående, at chefen i spørgsmålet om abonnement taler i korpsets navn. Kan han det? Men noget andet er, at obersten i mangt og meget har ret i sin anklage mod Flensborg Avis. Den pågældende artikel var yderst uheldig, og det er jo ikke sjældent, dette blad træder i spinaten. At det har hjulpet stærkt til at få den danske nazisme udbredt i Sønderjylland, er en kendt sag. Bladet søger at forsvare sig mod oberstens anklage og gør det under udfoldelse af den kvalmende selvgodhed, der altid præger bladets vurdering af dets eget arbejde; men det indrømmer dog at have trådt fejl. Bare det noget oftere kunne få øje på egne fejl, så ville megen skade kunne afbødes.«

Artiklen var efter al sandsynlighed forfattet af Sønderborg Socialdemokrats chefredaktør, Frede Nielsen.

Der herskede navnlig i venstreorienterede og venstreliberale kredse dyb mistillid til Flensborg Avis' stilling mellem demokrati og diktatur. Flensborg Avis havde nemlig jævnligt anket over fejl og mangler ved det danske parlamentariske demokrati og havde lejlighedsvis peget på forskellige forhold i Hitlers Tyskland som eksempler, der - tilpasset danske betingelser - var værd at efterfølge.

I Ernst Christiansens verdensbillede var modsætningerne stillet op: dansk kontra tysk; her gik for ham den afgørende skillelinje. For en dansk socialdemokrat så det imidlertid anderledes ud: her gik skille- 
linjen først og fremmest mellem demokrati og diktatur. Mens Ernst Christiansen således ikke nødvendigvis kunne se noget suspekt ved en antidemokrat, når blot han var dansk, så tog sagen sig anderledes ud for en socialdemokrat - og Paludan-Müller så på tingene på lignende vis. Der var en næsten uovervindelig forståelseskløft mellem parterne; man forstod ganske simpelt ikke hinandens sprog og hinandens tanker.

Redaktionen af Flensborg Avis modtog de følgende dage en lang række breve, nogenlunde ligeligt fordelt mellem afstandtagen og opbakning til avisen; enkelte forlangte offentlig bodsgang fra Tage Jessens side, hvilket Ernst Christiansen dog afviste med den uomgængelige motivering, at hverken avisen eller Den slesvigske Forening - det danske mindretals kulturelle og politiske talerør, hvis største afdeling, Flensborg-afdelingen, Tage Jessen var formand for - var tjent med at få sin stilling svækket offentligt. ${ }^{9}$ Bladets læsere måtte desuden udmærket være klar over, at det "aldeles ikke er bladets standpunkt, der er kommet frem i nogle vendinger i den udenrigspolitiske rubrik «, skrev Ernst Christiansen f.eks. til en læser. »Det pågældende stykke har jeg først fået læst, da det var trykt, jeg har tydeligt taget afstand fra det, og på ledende sted har bladet hundreder og tusinder gange tolket en anden opfattelse. Når sligt hænder i et andet blad, er der ikke en hund, der gør af det. Når en ungdommelig medarbejder laver et fejlgreb ved Flensborg Avis, så forfølges det som en kapitalforbrydelse med opfordringer til boykotning af det danske grænseblad, der i forvejen ved valuta-nedskæringen er bragt på afgrundens rand og må friste livet under tysk diktatur. Hvis nogen her skal rejse anklager, så synes det mig at være os på grund af manglende solidaritet ved grænsen. Man kan blive morkseer, når man ser, hvad tyskerne koncentrerer her og hvad man på den anden side mener at kunne tillade sig på dansk side. ${ }^{10}$

\section{Forsoning}

Grosserer J.C. Møller, en af Flensborgs absolut førende danske, henvendte sig den 4 . september 1935, dagen efter offentliggørelsen af Paludan-Müllers artikel i Hejmdal, til Ernst Christiansen med forslag om, at en forsamling af borgere måske på én eller anden måde kunne gå i aktion til fordel for Flensborg Avis. Ernst Christiansen erklærede heroverfor, at det da kun skulle glæde ham, men han syntes i øvrigt 
ikke at nære stor tillid til, at en sådan aktion ville føre til noget godt.

Som sagt, så gjort: J.C. Møller og en række andre gode danske flensborgere satte sig i bevægelse for at få forsonet redaktøren og obersten. Der blev om eftermiddagen telefoneret mellem Flensborg og Gråsten, og samme aften mødtes de to kombattanter - på neutral grund i Borgerforeningen i Flensborg og sekunderet af J.C. Møller og en række andre flensborgere - til en drøftelse af deres uenigheder. ${ }^{11}$

Samtalen rensede luften og endte i fordragelighed; obersten genbestilte abonnementet, ikke alene til grænsegendarmeriet, men endog til sig selv privat. Til Ernst Christiansen skrev Paludan-Müller dagen efter mødet, den 5. september 1935: "Modtag, hr. Redaktør, forsikringen om min mest udprægede højagtelse. - Således skriver diplomaterne, de mener det ikke; jeg mener det. De vil sikkert også have bemærket, at jeg ikke er diplomat. « ${ }^{12}$

Dermed kunne sagen være endt - men det gjorde den ikke. Den danske dagspresse havde meget at sige for og imod Paludan-Müllers drastiske abonnementsopsigelse, og sagen truede med at antage større udenrigspolitiske dimensioner, da den italienske gesandt den 5 . september dukkede op og gjorde indsigelse overfor det danske udenrigsministerium. ${ }^{13}$

\section{Sagen får følger}

Den 5. september 1935 var det store konservative hovedstadsblad $\mathrm{Na}$ tionaltidende/Dagens Nyheder, straks man havde set Paludan-Müllers indlæg i Hejmdal, rykket ud med en artikel om sagen. Bladet havde hidtil været noget tilbageholdende i sin redaktionelle stillingtagen til Abessinien-krisen - omend dens engelske korrespondenter, som bladet delte med den førende engelske avis Daily Telegraph, var stærkt kritiske overfor Italien. Det var den kendte redaktør Franz von Jessen, mangeårig ven af Flensborg Avis, der forte pennen: "Forstår oberstløjtnant Paludan-Müller ikke, at hans høje stilling pålægger ham forsigtighed med hensyn til, hvad han kan tillade sig af anklager mod en fremmed stat, måtte han dog i det mindste kunne begribe, at det ikke kan være hans, endsige grænsegendarmeriets sag at skolemesterere Flensborg Avis for dens anskuelser. At han på så opsigtsvækkende måde lader den statsinstitution, han leder, insultere det danske grænseblad og tage standpunkt $i$ en konflikt, med hensyn til hvilken den danske stat er neutral, er en taktløshed og en utilbørlighed, som øje- 
blikkelig må redresseres. Offentligheden venter et nyt - og mere taktfuldt - initiativ fra oberst Paludan-Müllers side."

Det var efter alt at dømme denne artikel, der gjorde den italienske gesandt opmærksom på Paludan-Müllers artikel i Hejmdal. Sagen måtte nu overvejes af udenrigsministeren.

Det var et led i dansk udenrigspolitik i 1930'erne at formå den danske presse til at vise selvbeherskelse $i$ omtalen af andre lande navnlig i omtalen af de utilregnelige diktaturstater, der ikke viste megen forståelse for principperne for en fri presse. I offentlige taler manede navnlig statsminister Th. Stauning og udenrigsminister P. Munch jævnligt pressen til at omtale specielt Tyskland med større forsigtighed. Og på jævnlige fortrolige møder »orienterede« $P$. Munch de store dagblades redaktører om Danmarks stilling i den udenrigspolitiske situation. Disse »orienteringer« var forsøg på at knytte dagbladene til regeringens udenrigspolitik og forpligte dem på en behersket og mådeholden udenrigsdækning. Det var ikke i Danmarks interesse, at dets presse fornærmede udenlandske statsoverhoveder. Effekten af disse »orienteringer " var dog blandet, eftersom ikke mindst regeringspartiernes egne blade med Socialdemokraten og Politi$k e n$ i spidsen vedblev at forholde sig stærkt kritiske til diktaturstaterne i Europa.

Over for pressen var der $i$ et frit og demokratisk land ikke de store sanktionsmuligheder. Det så anderledes ud, hvis en af statens egne embedsmænd var synderen. I tilfælde af statsminister Th. Staunings og udenrigsminister P. Munchs fravær - som det var tilfældet $i$ begyndelsen af september 1935 - fungerede finansminister H.P. Hansen, der var socialdemokrat, som stats- og udenrigsminister. Det var altså H.P. Hansen, der måtte lægge øre til den italienske klage. H.P. Hansen var samtidig Paludan-Müllers øverste chef, eftersom grænsegendarmeriet hørte ind under Finansministeriets Departement for Told og Forbrugsafgifter.

I Departementet for Told og Forbrugsafgifter gjorde man sig i løbet af dagen visse overvejelser om, hvordan denne prekære sag bedst kunne gribes an: Artiklen i Hejmdal stødte formentlig imod straffelovens $\S 108$, der truede den, der offentligt forhånede en fremmed nation, en fremmed stat, dens flag eller andet anerkendt nationalmærke, med bøde, hæfte eller - under skærpende omstændigheder - med fængsel indtil ét år. Påtale fandt imidlertid kun sted, hvis det udtrykkeligt blev forlangt af vedkommende fremmede regering. 
I Finansministeriet anså man det for en skærpende omstændighed, at Paludan-Müller var embedsmand, tilmed i fremskudt stilling ved grænsen, samt at artiklen var signeret ikke alene med hans navn, men også med hans tjenestestilling. Påtalen var jo imidlertid afhængig af, at den fornærmede fremmede regering beklagede sig, hvad Italien på dette tidspunkt - den 5. september 1935 - endnu ikke officielt havde gjort. Hvis dette skete, ville den offentlige påtale da ske efter Justitsministeriets påbud og sagen skulle da behandles ved en nævningedomstol.

Det er ikke anført i departementets overvejelser, men det har formentlig indgået $\mathrm{i}$ disse, at en sådan model utvivlsomt ville vække en del opsigt $i$ offentligheden - og når afgørelsen var lagt $i$ hænderne på en nævningedomstol, var det heller ikke givet, at resultatet ville falde ud til den italienske gesandts tilfredshed: To år tidligere havde kommunisten Aksel Larsen på havnen i Aabenraa revet et hagekorsflag itu og omtalt det som et "morderflag". Den tyske gesandt havde insisteret meget stærkt på en retssag - der var endt med Larsens frifindelse. Forinden havde sagen vakt kolossal opsigt i offentligheden, og det samme kunne meget vel ske i en eventuel sag imod Paludan-Müller. Dette ville hverken være i Danmarks eller Italiens interesse. Det havde desuden dengang kostet megen anstrengelse at gøre det tyske gesandtskab begribeligt, at de danske domstole var uafhængige, og at den danske regering derfor ikke kunne ændre dommen.

Men sagen kunne måske også afvikles på en mindre dramatisk måde efter tjenestemandsloven. Det syntes nemlig oplagt, at PaludanMüller havde gjort sig skyldig i en tjenesteforseelse ved i sit brev til Flensborg Avis og i sit avisindlæg at have henvendt sig i tjenstlig form. Dette kunne betragtes som en overtrædelse af tjenestepligterne. Tjenestemandslovens $\S 3$ pålagde nemlig tjenestemanden $i$ alle anliggender samvittighedsfuldt at overholde de for hans tjenestestilling givne love, anordninger og forskrifter, og han skulle $i$ sine forhold $i$ og udenfor tjenesten vise sig værdig til den agtelse og tillid, som hans stilling krævede. Dette synes Paludan-Müller altså efter Finansministeriets mening ikke at have gjort, da han opsagde sit abonnement.

Man havde imidlertid i Finansministeriet noteret sig, at der ifølge dagens B.T. - formiddagspressen blev også studeret $i$ statsmagtens departementer - skulle være sluttet et forlig mellem parterne, og at der skulle være opnået en for Flensborg Avis tilfredsstillende ordning. 
Denne del af sagen syntes altså at være ude af verden. Men i modsat fald var man indstillet på at pålægge Paludan-Müller: at tilbagekalde sine udtalelser, at beklage at de var fremsatte, og at genoptage abonnementet på bladet.

Skulle det ikke blive nødvendigt at foretage sig yderligere i sagen, måtte den under alle omstændigheder afsluttes med en alvorlig misbilligelse $i$ overensstemmelse med tjenestemandslovens $§ 18$, idet det samtidig skulle pålægges Paludan-Müller fremtidig ikke offentligt at fremsætte påstande om fremmede magter.

Det blev besluttet at indkalde Paludan-Müller til en tjenstlig samtale. ${ }^{14}$ Indkaldelsen skete straks samme dag, og dagen efter, den 6. september 1935, modte Paludan-Müller op i Finansministeriet. Her talte han med finansminister H.P. Hansen, generaldirektør i Finansministeriet Knud Korst og kontorchef i Departement for Told og Forbrugsafgifter Michael Kofoed. Der er tilsyneladende ikke bevaret nogen referater af disse tjenstlige samtaler, men det er ikke svært at gætte sig til, hvad der er sket: Paludan-Müller har erkendt sit fejltrin og har fået en alvorlig røffel. Men dermed var sagen ikke endt for ham. Han blev også præsenteret for afgørelsen i den tjenestemandssag, der allerede dagen før var blevet indledt.

Kendelsen faldt den 6. september 1935 og lød som følger: »I anledning af Deres i bladet Hejmdal for den 3. ds. optagne artikel vedrørende de italienske-abessinske forhold, hvori De har fremsat en række for den italienske stat krænkende udtalelser, meddeler man Dem herved $i$ henhold til tjenestemandsloven $\S 18$ en alvorlig misbilligelse, hvorhos De ikendes en bøde på en halv måneds løn, lige som man yderligere skal tilkendegive Dem, at De fremtidig i Deres nuværende stilling hverken som Chef for Grænsegendarmeriet eller som privatmand og hverken skriftligt eller mundtligt må udtale Dem offentligt om forhold som det ovennævnte eller om forhold af lignende karakter, $i$ alt fald ikke uden at De $i$ de enkelte tilfælde forud har indhentet administrationens tilladelse, og at De må forvente $i$ gentagelsestilfælde øjeblikkelig at blive afskediget. De vil derhos have at tage orlov fra tjenesten indtil videre. ${ }^{15}$

Der er grund til at tro, at den lynhurtige dom og dens øjeblikkelige ikrafttræden har tilfredsstillet det italienske gesandtskab. ${ }^{16}$ Afgørelsen blev samme dag meddelt pressen officielt. 


\section{Pressen tager stilling}

Dansk dagspresse delte sig i to på spørgsmålet: De borgerlige aviser skrev om et "afskyeligt overfald på Flensborg Avis «" ${ }^{17}$ og enkelte lod harmen få frit løb over for Paludan-Müllers »usømmelige « og »uretfærdige « handling. Det blev fremhævet, at hans angreb på Flensborg Avis ville vanskeliggøre bladets i forvejen vanskelige situation, og enkelte blade krævede oberstens afgang.

Også de borgerlige sønderjyske aviser sluttede sig i et vist omfang til kritikken af Paludan-Müllers adfærd: Haderslev-avisen Modersmaalet fandt Paludan-Müllers opførsel i denne sag »utilbørlig«, "usømmelig " og "taktløs - uanset at man, hvad man understregede, i øvrigt ikke var enig i de betragtninger, Flensborg Avis havde fremsat om den italiensk-abessinske konflikt. ${ }^{18}$

Hejmdal fulgte sagen på afstand, refererede loyalt - og meget kortfattet - om sagens udvikling, men tog ikke selv stilling $i$ sagen. ${ }^{19}$ Hejmdals tavshed er så påfaldende, at den må tages som et udtryk for, at redaktionen ikke var ret stolt over den rolle, avisen havde spillet $i$ denne sag.

Jydske Tidende forholdt sig afventende. Avisen kunne den 6. september 1935 bringe et interview med Paludan-Müller, hvori han meddelte, at der var sluttet venskabeligt forlig mellem ham og Flensborg Avis - og at han havde gentegnet abonnementet. Han erklærede desuden, at han udelukkende havde undertegnet sig med sin titel, fordi man ikke kunne forvente, at folk ellers ville vide, hvem han var.

Da det blev kendt, at Paludan-Müller havde fået tildelt misbilligelse og tvungen orlov på ubestemt tid, blev dette hilst med nogen tilfredshed i dele af den borgerlige presse. Enkelte anstillede betragtninger over, hvorvidt han overhovedet atter burde genindtræde, mens andre hæftede sig ved, at han nu var blevet forsonet med Flensborg Avis, og at sagen var bedst tjent ved at der faldt ro over den. Som dagene gik, blev det mere og mere en "beklagelig affære «. ${ }^{20}$ Man erkendte, at Paludan-Müller havde forløbet sig, men anførte, at han dog kun udtrykte samme holdning, som dansk presse i månedsvis havde indtaget. ${ }^{21}$ Der var udbredt enighed om at beklage affæren. Men stort set samtlige dagblade var meget omhyggelige med at lægge afstand til stridens årsag: Flensborg Avis' betragtninger over konflikten i Afrika.

For eksempel den sønderborgske venstreavis Dybbøl Posten fremhævede i en leder den 7. september 1935, at Paludan-Müller var kendt 
som en forstående og stærkt nationalt sindet mand, der nu blot i sin ilterhed havde forløbet sig. "Selvom det måske er forståeligt, at oberst Paludan-Müller har følt sig harmfuld over de betragtninger, Flensborg Avis offentliggjorde vedrørende det Abessinske spørgsmål, betragtninger, som også vi for vort vedkommende vil tage bestemt afstand fra, tør det nok antydes, at han har båret sig særdeles ubehændigt ad, mere ubehændigt, end en mand i en så fremtrædende stilling har lov til det! Det er ikke alene en utilgivelig dumhed, han har gjort sig skyldig i, men en utilbørlighed, som måtte påtales fra højeste sted.« Han burde ikke have udtalt sine private meninger i sin egenskab af fremtrædende embedsmand, og at Paludan-Müller siden havde forsøgt at bortforklare denne detalje med, at han kun havde anført sin stilling, fordi han jo ikke kunne forvente, at folk ellers ville vide, hvem han var, tog Dybbøl Postens lederskribent - efter alt at dømme Kai Edvard Larsen - ikke for gode varer; dette var »en undskyldning af en så tåbelig beskaffenhed, at den helst ikke burde være undsluppet sin ophavsmand«. Dybbol Posten mente dog, at der nu var givet Paludan-Müller en så alvorlig tilrettevisning, at han fremtidig ville vide at bevæge sig med større forsigtighed, og "vi tør vel gå ud fra, at hans orlov kun vil være at betragte som en hårdt tiltrængt ferie ovenpå denne abessinsk-italienske forpostfægtning. Oberstens faglige kvalifikationer er der næppe nogen, der vil bestride, og det er os bekendt, at han i den tid, han har stået som gendarmeriets chef, ellers i øvrigt har vist sig sin plads voksen."

Dybbøl Posten ville tydeligvis nødig af med Paludan-Müller.

Den anden Sønderborg-avis, Sønderborg Socialdemokrat, var endnu mindre glad for den opståede situation, som man i en ledende artikel den 8. september 1935 dog først og fremmest gav Flensborg Avis' "ubegribeligt dumme artikel om det abessinske spørgsmål « ansvaret for. Sønderborg Socialdemokrat, der jo kun vanskeligt kunne polemisere åbent imod en beslutning, truffet af den socialdemokratiske finansminister, medgav, at det havde været en fejltagelse af obersten at tale $i$ korpsets navn $i$ en sag af denne art, og beklagede, at finansministeren ikke havde haft andet valg end at følge tjenestemandslovens bestemmelser.

Embedsmænd måtte lære at holde deres personlige følelser og anskuelser borte fra deres optræden som embedsmænd - dette var den lære, der kunne drages af det skete, fandt Sønderborg Socialdemokrat. 


\section{-Selvgodhed?}

\section{I et Stykike om sFlensborg Arise,} hrori det coclaldemokratiske Blad I Nordeleovig dog antyder nogen Med$\mathrm{hu}$, for ilke at sigo Solidaritet, sveber Bladet - modsat Apotokeren denne mildo Karno ind 1 en bitter Skal ved at talc om skvalmende Selvgodheds.

Om and narvacende Blad aldrig vil kunne gere sig Hasb om at blivo regnet for saa beskedent or uselvisk som det socialdemokratisko Blad, san or dor dog on Misforstanclse $i$ det. navnte, flere Gango brugto Slagord.

Forleden var en Kreds af Medarbejdere samlet til en lille privat Festlighed for en Kammerat, hvis Arbojde fyldte et sterre Aaremaal, uden at det onskedes navnt i Offentligheden. Der bler sagt $i$ on Tale, at det falder ikke nogen af os ind at have ondt at os selv, fordi der i Arbojdet ved et sia udsat Dagblad har varet et og andet at slaas med. Et saadant $\Lambda$ rbcjdssted for en saadan Sig er on lykkelig Livs. opgave. I en anden Tale blev der navnt en Rakke Navne fra Bladets Historie og sagt: De enkelte kormer og gaar, men Avizen bestaar!

Der har flere Gange varet Tider, da Trusierne blev overliangende, men Solin aprongte Skydarkket pata ny.

Det or ikke helt ligetil al forklaro Midarbejdernes Indutilling, der or mero folclsosmessig, grocl kngwomt igrnurm mange Anrs Oplovelso, igen. nem on livagenilng fre de ungo langr, rnd nngen Sinde klarlagt I nnjngtig Udformning.
For os er Avisen ot Mierke eller more end dot: et Svard og on Plov. Svardet har sunget i san mangen dra] Dyet, mon dog; hvor Stimlen var trettost og Faren storst, med lys klang meldt om dansk Livamod I Senderjylhand. Svardot har lydt haradt of rnedt som Skrop, I Vintomio har Klangen mindot om Is, der slog Revner, men tot har ogona tonct fryde. fuldt I Vaar. Og udon at det micrkodes, var Sviendot holo Tidon antldig smedct on tll Plov, og Plovjornet skar nod, dybt nod under lyng og K rat, of sngte at brydo Ainn I Slosvign Jord. surerd- og Flarmmndone nklitodo, mon Jernot lortsatle sin Bang.

Hvilknt Vald at Minder or der fkke at uso at om markeligo Oplevolser, og dog blivor der nesten . aldrig Tid ill det, fordi dor stadig leves nyt og nyo speendande Dage.

Det er rigtigt, at dc, der arbejder ved de danske Forposters Blad, sor op til det som noget stort. De mener ikke at overnirdere sig selv, at regne sig selv for sarlig henaadedo eller mere fejlfrie end andre Mennesker. Mon i Forsvaret for en stor Sag veed de, at de har overtaget en fremskudt, farlig og forjottende Post, en hetydringsfuld Arv, ot Vaaben, et Redskah, som aldrig kan tores med udeltagende ligegyldighed, men bestandig pas ny kraver hele Manden.

Tidon slider paa os alle, men hvor vilde vi dog enske, at vi igennem vor Folkcarv kundo fyldes med an ydmyg Stolther saa levendo og sojronde, at ingen kundo stas imod over for Sonderjyllands Sag.

Redaktør Frede Nielsen på Sønderborg Socialdemokrat beskyldte Flensborg Avis for at lide af „kvalmende selvgodhed ". Dette afviste redaktor Ernst Christiansen pd Flensborg Avis $i$ den ledende artikel fra 6.9.1935, som er vist her. Men lige akkurat den slags nationalromantisk bragesnak, som Ernst Christiansen diskede op med $i$ sin leder - og som var meget typisk for hans poetiske skrivestil i avrigt - virkede stærkt ophidsende på socialdemokratiske sind. Socialdemokraters egne retoriske kraftudladninger havde - $i$ parentes bemærket - ofte en tilsvarende effekt på borgerlige læsere. 
Men "ser man bort fra denne utilgivelige fejl, vil man give hr. Paludan-Müller ret $\mathrm{i}$ hans skarpe angreb på Flensborg Avis. Artiklen, han angreb, var til det yderste udfordrende og dum, og bladet fortjente en yderst kraftig lære om, at nu skal det ikke øse mere op af den tønde. Der er andre sider af bladets journalistik, der også fortjener en kraftig visker. Det er snart ikke andre end bladet selv, der er imponeret over dets præstationer. Alle andre kan ikke andet end fæste opmærksomheden ved dets mange svagheder. I en spidsartikel i forgårs beskæftigede bladet sig med vor påvisning forleden af dets osende selvgodhed. Det søger igen i denne artikel at stille sig i relief, men opnår kun atter at bekræfte rigtigheden af vor påstand om dets selvforgudelse og selvforblindelse. Ja, bladet kunne være værdifuldt, hvis der skete en radikal ændring i dets forhold, og det så fik den stærkt tiltrængte blodfornyelse.«

Dette var jo unægteligt talt lige ud af posen fra redaktør Frede Nielsens side.

Også den socialdemokratiske fører i Sønderjylland, folketingsmedlem J.P. Nielsen fra Dynt, tog affære $i$ anledning af Paludan-Müllersagen. Han omtalte sagen på et stort socialdemokratisk møde i Brunsnæs på Broagerland den 8. september 1935, og han skrev samme dag i et brev til partifællen, finansminister H.P. Hansen: "Må jeg få at vide, hvad der mere skal ske med Paludan-Müller? Helst omgående; thi vi er ved at organisere protester, nedsætte udvalg o.s.v. For os er det meget uheldigt af flere grunde, som jeg ikke vil skrive om, men sige dig personligt. Kun så meget, at vi må i høj grad balancere, hvis vi ikke vil have slået for meget i stykker. «"22

Det var tydeligvis ubekvemt for de sønderjyske socialdemokrater at skulle fremstå som svage over for de italienske fascisters fremfærd i Afrika - eller endog som vogtere af Mussolinis ære, hvor man langt hellere med svingende faner ville have sluttet sig til Paludan-Müllers anti-fascistiske felttog. ${ }^{23}$

\section{Sagen tilspidses}

Der var ved at falde ro over sagen, da gendarm J. Petersen fra Padborg den 10. september 1935 indrykkede et læserbrev i Sønderborg Socialdemokrat, der atter satte fuldt blus under debatten. Heri hed det bl.a. med en henvisning til Paludan-Müllers tvungne orlov: "Den vending, som er foregået i sagen, er kommet for alle som en overraskelse, 


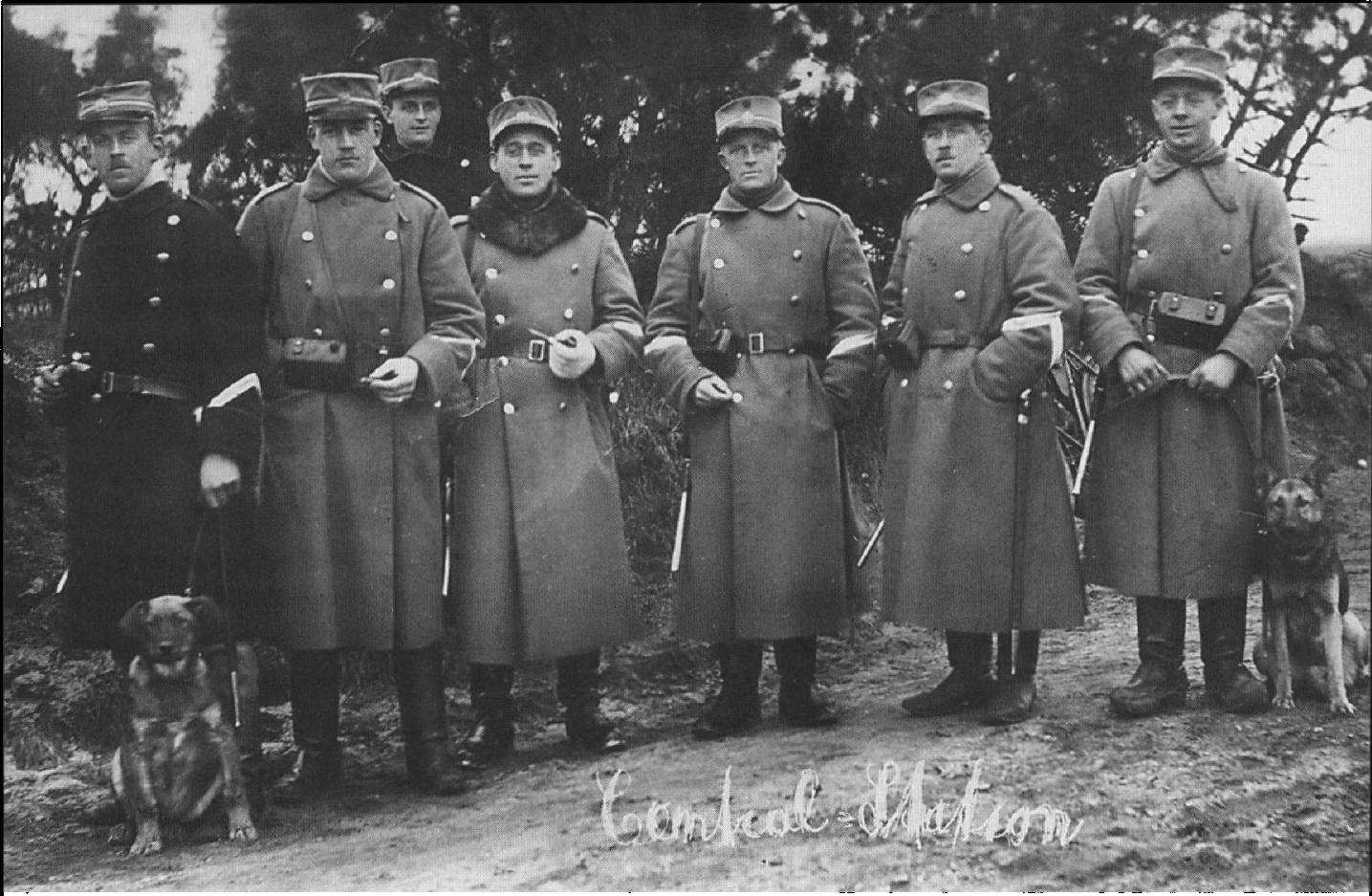

"Som Gøngerne, da Svend Poulsen var fange på Jungshoved og skulle skydes. « Sådan opfattede Paludan-Müller stemningen blandt grænsegendarmerne, da han skiltes fra dem p.g.a. sin tvungne orlov. En gruppe grænsegendarmer ses her fotograferet omkring 1930. Den uheldige laserbrevsskribent, Jorgen Petersen, er nr. 5 fra venstre. "Røde Jørgen «, som han blev kaldt, markerede sig som aktiv socialdemokrat $i$ lokalpolitikken, bl.a. som medlem af Bov sogneråd og formand for Bov Sogns skoleudvalg.

Foto $i$ Bov lokalarkiv.

idet ingen havde tænkt sig, at indholdet i den omstridte artikel - som for avrigt ethvert fredselskende menneske kunne tiltræde - kunne medføre sådanne konsekvenser, som sket er. Det må meget beklages, at artiklens udenrigspolitiske tilsnit er kommet $\mathrm{i}$ strid med tjenestemandsloven og derved har spillet Flensborg Avis sejrens palmer i hænde. Artiklens indhold er dog derfor på ingen måde blevet afkræftet, men har stadig beholdt sin sande værdi. Obersten har i den korte tid, han har været chef for grænsegendarmeriet, vundet hele personalets agtelse og tillid, og denne vil på ingen måde blive svækket af det forefaldne - tværtimod. Den dom, der er overgået ham, og som det er den almindelige mening, at Flensborg Avis har forårsaget, har vakt en stærk harme blandt personalet, og det må håbes, at denne harme må resultere i, at man i alle gendarmhjem, hvor Flensborg Avis hidtil har holdt sit indtog, hurtigst muligt lukker for bladet.«

Hertil føjede redaktionen af Sønderborg Socialdemokrat dog følgende: "Vi har gentagne gange fremhævet, at vi og utvivlsomt det store fler- 
tal i realiteten er enig med hr. Paludan-Müller; men han kan ikke skrive som dansk embedsmand så voldsomt imod en europæisk magt. Striden med Flensborg Avis har næppe spillet nogen som helst rolle m.h.t. ministerens afgørelse.«

Med gendarmens læserbrev var sagen påny blevet antændt. I samme nummer blev der desuden bragt et referat af den tale, som folketingsmand J.P. Nielsen havde holdt i Brunsnæs på Broagerland den 8. september 1935. Heri kom han også ind på Paludan-Müller-sagen, og udtalte bl.a.: "Det var en fejl af hr. Paludan-Müller at optræde i sit korps' navn, det kan man ikke gøre $\mathrm{i}$ en sådan sag. Vi beklager det skete, thi Paludan-Müller var en god chef for grænsegendarmeriet. Hvor meget der skal ofres på Mussolinis alter $\mathbf{i}$ denne sag ved jeg ikke, men det får vi sikkert snart at vide. Men så kommer jeg til ophavet til affæren, nemlig en artikel i Flensborg Avis, der faktisk forsøgte at gøre Italiens overfald på Abessinien forsvarlige. Flensborg Avis støttes i høj grad af den danske stat, men en sådan opfattelse er fuldkommen i strid med den danske stats interesser. Danmark som lille stat har kun at håbe på, at retten sejrer, således at man gensidig respekterer hinanden. Sættes retten i spydstagen eller i maskingeværer og bombeflyvere, så vil det snart være ude med de små staters selvstændighed. Jeg tror nu ikke, at Flensborg Avis vil høste fordel af den historie. I de 24 timer, der er gået siden hr. Paludan-Müller fik orlov, har jeg fået masser af henvendelser, organisationen indkaldes til møde, udvalg nedsættes o.s.v. Sagen er den, at alle med undtagelse af Flensborg Avis er enige med Paludan-Müller i hans fordømmelse af Italiens overfald på Abessinien. Kun var man uenig med ham om formen og måden, hvorpå han fremsatte sine anskuelser.

Jeg tror, at det ville være heldigt for Flensborg Avis, hvis det kunne finde sine egne ben og blive talerør for det danske mindretal syd for grænsen og lade både storpolitikken i Verdens Gang og venstrepolitikken fare. Se på det tyske mindretalsblad i Nordslesvig; det er altid på tæerne for at varetage mindretallets interesse og stille krav til den danske herbergsstat. Flensborg Avis er efterhånden blevet en defensor for Det tredje Rige og altid parat til at falde dansk administration $\mathrm{i}$ ryggen. Og det kan da ikke være varetagelse af danske opgaver, slet ikke af den danske stats interesser."

Så rullede lavinen igen: Nationaltidende/Dagens Nyheder, hvis Aabenraa-korrespondent havde indtelefoneret et referat af Sonderborg Social- 
demokrats artikler, rykkede nu ud den 11. september 1935 med et stærkt angreb på J.P. Nielsen, idet man dog som følge af en fatal kommunikationsfejl kom til at blande J.P. Nielsens udtalelser og gendarm Petersens læserbrev sammen. Der herskede efter Nationaltidende/Dagens Nyheders mening et tilsyneladende anarki i Socialdemokratiet, eftersom det sønderjyske folketingsmedlem således offentligt undsagde sin minister. Det var endvidere »angiveri«, når J. P. Nielsen hævdede, at gendarmerne brød sig fejl om ministerens irettesættelse af deres chef, og at irettesættelsen snarere ville styrke end svække deres agtelse for og tillid til ham. "Således sørger hr. J.P. Nielsen for, at regeringen stadig holdes $i$ arbejde. Chefen for grænsegendarmeriet misbilliger i Hejmdal Flensborg Avis, regeringens chef misbilliger grænsegendarmeriets chef, grænsegendarmeriets personale og folketingsmand J.P. Nielsen misbilliger regeringens chef, og regeringens chef misbilliger hr. J.P. Nielsen og grænsegendarmeriet. Det er skruen uden ende. Man skulle tro, man var i et galehus«, sluttede Nationaltidende/Dagens Nyheder sin ledende artikel.

Det var noget af en journalistisk brøler at blande J.P. Nielsens udtalelse sammen med gendarmens læserbrev, og Nationaltidende/Dagens Nyheder fik dagen efter prompte sagen i hovedet igen af den samlede socialdemokratiske presse under en byge af vredesudbrud som: »en række løgnagtige påstande«, "skamløs«, "perfid«, "gemenhed «, »et smudsigt felttog", en »skandaløs smædeartikel«, "sjofelt«, og »et uhyggeligt eksempel på perfid og uansvarlig journalistik «. Nationaltidende/Dagens Nyheder havde overtrådt de uskrevne love for debatten mellem dagbladene: Man havde ikke refereret sin modstander loyalt. Redaktør Franz von Jessen - dansk journalistiks grand old man og meget ærekær både på egne og på journaliststandens vegne - måtte krybe til korset, dybt beklage fejlen og undskylde over for J.P. Nielsen og Sonderborg Socialdemokrat. ${ }^{24}$ Dermed var Nationaltidende/Dagens $\mathrm{Ny}$ heder udskilt af debatten.

\section{Paludan-Müller intervenerer}

Gendarm J. Petersens læserbrev og fejden mellem de danske dagblade fik atter Flensborg Avis til at rykke ud: Det var en "trist foreteelse", at et indlæg som J. Petersens var muligt ved den danske grænse, "hvor der burde være enighed om med fuld kraft at slutte op om de danske forposter og deres presse, der har værget disse egne i menne- 
skealdre«, skrev Ernst Christiansen den 11. september 1935. »Uden tvivl er det dog kun enkeltmand, der står bag ved dette indlæg, og det kan ikke tænkes at få nogen virkning. Hvem der angriber Flensborg Avis nu, har aldrig hørt til bladets venner og har næppe læst, hvad bladet har skrevet. De hjem, der med kærlighed har fulgt bladet og dets virke, vil snarest slutte tættere op omkring det. I øvrigt har bladet grund til at antage, at grænsegendarmeriets chef bestemt misbilliger ethvert boykotningsforsøg.«

Dette var mere end blot en antagelse. I mellemtiden havde Ernst Christiansen og Paludan-Müller nemlig påny vekslet breve. PaludanMüllers brev er ikke bevaret, men er formentlig dateret den 10. september 1935 og er kommet Ernst Christiansen i hænde samme dag eller dagen efter. Det har formentlig indeholdt en afstandtagen over for J. Petersens læserbrev og en lykønskning $i$ anledning af Ernst Christiansens fødselsdag den 10. september 1935. Ernst Christiansen svarede den 11. september 1935: "Kære Hr. Oberst! Det har glædet mig meget at læse Deres brev og deri få indtrykket fra vort samvær fuldt ud bekræftet. Jeg må tilføje, at det har gjort mig ondt, at regeringen, formentlig efter italiensk pression, har taget så skarpt på sagens udenrigspolitiske side. Tak for Deres lykønskning. Jeg nærer et varmt ønske om en god fremtid for Dem. Deres hengivne Ernst Christiansen."

Der er ikke nogen umiddelbar grund til betvivle, at Ernst Christiansen mente sine ord. Han havde ganske vist været både vred og såret over Paludan-Müllers artikel, men tidens omskiftelser havde gjort Ernst Christiansen til en sagtmodig mand, der om nogen i grænselandet var vant til - og nødt til - at bide fornærmelser i sig. Han havde desuden nået til den erkendelse, at han uden forsoning med sine danske modstandere og uden en samling af den danske front aldrig ville nå sine politiske mål - der på langt sigt indebar en ny national afgørelse for Sydslesvig. Han var desuden med sin avis' stadigt forværrede økonomi blevet dybt afhængig af tilskud fra den danske regerings side - og den danske regering bestod af de partier, der havde været hans modstandere i grænsekampens dage, Socialdemokratiet og Det radikale Venstre.

Paludan-Müller sendte i øvrigt den 11. september 1935 Ernst Christiansens brev videre til kontorchefen i Departementet for Told og Forbrugsafgifter til orientering for generaldirektøren og ham selv angående Paludan-Müllers nuværende hjertelige forhold til Flensborg Avis. ${ }^{25}$ 
Paludan-Müller gjorde med andre ord sit for at dæmpe gemytterne. Som han den 11. september 1935 skrev til generaldirektøren i Finansministeriet: "Hr. Generaldirektøren må tro, at jeg nøje har overholdt ånden i det mig givne pålæg: At gøre alt for at få bølgerne til at lægge sig. Jeg har ikke været $\mathrm{i}$ uniform siden min hjemkomst og har arbejdet hver dag med at berolige sindene og lægge alt til rette for kaptajn Ørsted-Petersen, der egentligt har nok at gøre med sit store distrikt. Gendarmerne har nærmest været som Gøngerne, da Svend Poulsen var fange på Jungshoved og skulle skydes. Dagen i dag har været meget bevæget, jeg har ordnet gendarm Petersens utroligt klodsede bjørnetjeneste, talt med formanden for gendarmeriforeningen og sendt pålideligt og indtrængende bud til J.P. Nielsen om endelig at holde sig i ro. Jeg har formået en god bekendt af redaktør Schoch til at skrive til denne og bede ham indstændigt om at standse veltalenheden i Dagens Nyheder. Hvis jeg var rejst bort straks, var det gået meget værre. Forst nu kan jeg rejse, og jeg rejser i morgen tidlig og bliver borte en tid. ${ }^{26}$

Gendarm J. Petersen lod da også den 11. september 1935 følgende indlæg indrykke i Sonderborg Socialdemokrat: "Efter at mit indlæg i Socialdemokraten i går angående striden mellem Flensborg Avis og grænsegendarmerichefen er blevet læst, har jeg modtaget sådanne oplysninger, om den stilling, Flensborg Avis' redaktion har indtaget i denne pinlige sag, at jeg ikke opretholder tvivlen om bladets værdi i den nationale kamp, og at jeg naturligvis ikke derefter vil søge modarbejdet, at bladet finder den fornødne støtte

Dette indlæg var uden tvivl en direkte følge af Paludan-Müllers intervention. Men dermed var sagen ikke endt endnu. Og debatten blev ivrigt fulgt i den øvrige danske presse med indlæg for og imod Flensborg Avis. ${ }^{27}$

\section{Flensborg Avis mellem demokrati og nationalsocialisme}

Debatten udviklede sig nu til et opgør om Flensborg Avis' stilling til nazismen. Ernst Christiansen følte sig, p.g.a. angrebene i Sønderborg Socialdemokrat og beskyldningerne for at fremme nazismen, tvunget til den 11. september 1935 atter at tage ordet $i$ en to fulde spalter lang ledende artikel. Heri kom han endnu engang ind på Flensborg Avis' principielle stillingtagen til den tyske nazisme - et spørgsmål, som 
avisen gentagne gange igennem de seneste to et halvt år var blevet afæsket en klar stillingtagen til, men som man - på trods af megen anvendt spalteplads - aldrig havde besvaret til kritikernes fulde tilfredshed.

Det kommunistiske Arbejderbladet og Sønderborg Socialdemokrat havde bebrejdet Flensborg Avis dens linje over for Tyskland, og Ernst Christiansen stillede sig ikke ganske uforstående heroverfor. Ernst Christiansen anførte dog, at Flensborg Avis i sine bestræbelser på at dømme upartisk havde fremhævet, at det bedste $\mathrm{i}$ alle »de nye bevægelser « - herunder altså også kommunismen - ville komme til at sætte sit [positive] præg på menneskeslægtens nærmeste fremtid. Man havde altså ikke kun forholdt sig velvilligt neutralt over for nationalsocialismen, men også over for kommunismen.

Et sådant forsvar var dog dømt til at prelle af på enhver kommunist, der meget gerne ville have sig frabedt at blive ligestillet med nazisterne som sammenlignelige "nye bevægelser". Socialdemokraternes kritik af Flensborg Avis' linie over for nationalsocialismen var efter Ernst Christiansens mening nok forklarlig på baggrund af dets søsterpartis skæbne i Tyskland, men han forstod den dybest set ikke.

Ernst Christiansen anførte indledningsvis, at såfremt Flensborg Avis havde fulgt en anden linie end den, den havde ført de seneste år, "så ville det næppe mere have været blandt de levendes tal « - en antydning af, at det ikke var ligetil at skrive en avis i Hitlers Tyskland. Men, fortsatte Ernst Christiansen: Den valgte linie skyldtes $i k k e$ udelukkende dette hensyn; man havde handlet "ud af sin egen inderligste overbevisning om, hvad der fremmer vort folks tarv«. Der var nemlig ikke blot brug for årvågenhed og tilbagevisning af folkelige overgreb og usandheder om Danmark, men der var også brug for "et utrætteligt, målbevidst arbejde for et godt naboforhold « mellem Danmark og Tyskland.

Det var dette, der var essensen af Ernst Christiansens "Front og Bro«-ideologi, som den havde udviklet sig efter Hitlers magtovertagelse i 1933, national selvhævdelse og mellemfolkelig forståelse: "Netop $i$ en farlig tid, da der truer et tilbagefald til skarpe og hadefulde modsætninger, må et dansk grænseblad huske sin dobbelte opgave som vagt og bro og må gøre sit til at bygge en fremtidsvej.« Der måtte vises saglighed og tro over for det nye Tyskland: "Et dansk grænseblad har ikke lov til at lade sig blinde af partipolitiske kredses yderligtgående fordømmelse af en bevægelse, der er slået igennem i 
det store naboland, som noget, der kun er fyldt af livsens ondskab. Der må fastslås, hvad der i øvrigt på tilsvarende måde gentagende er tilkendegivet både af den danske statsminister og den danske udenrigsminister, at det tyske folk må ordne sine ting efter sit eget hoved, og det er mellemfolkeligt set ikke af vejen at indrømme, at der ved siden af de ting, som dansk livssyn umiddelbart afviser, også er gode tanker med i spillet. Det er oven i købet den saglige sandhed, som det danske folk for sin egen skyld stăr sig ved at erkende.« Man skulle ikke $i$ en vanskelig tid gøre ondt værre mellem de to folk, men vise både besindighed og fasthed.

Ernst Christiansen forsøgte her at stille sig i ly af statsminister Staunings brede skikkelse og udenrigsminister Munchs tørre saglighed. Tyskland havde nemlig efter Hitlers magtovertagelse ikke lagt skjul på, at det betragtede kritik fremført af et andet lands presse som en uvenlig handling fra det pågældende lands side. Det tyske gesandtskab fulgte dansk dagspresses dækning af begivenhederne i Tyskland med stor opmærksomhed og klagede ofte og højlydt; presseattché Karl Frielitz sled trapperne foran det danske udenrigsministerium, belæsset med formentlig fornærmende udklip fra dansk dagspresse. Det var med andre ord et spørgsmål af udenrigs- og sikkerhedspolitisk betydning, hvad der stod i de danske aviser. ${ }^{28}$

En sådan forsigtig holdning over for Tyskland burde efter Ernst Christiansens mening finde tilslutning hos alle roligt overvejende kredse i Danmark - og fik det altså også i høj grad hos Flensborg Avis. Men at man fortsat på Flensborg Avis i efteråret 1935 kunne finde "gode tanker « i nazismen, spillede tydeligvis også ind. Der var åbenbart noget at lære af Hitler, selvom dette skulle tilpasses danske forhold.

Flensborg Avis havde fra første færd uforbeholdent sluttet sig til den "danske og nordiske frihedslinie", fortsatte Christiansen. Hvor bladet havde kritiseret danske forhold, havde formålet altid været at "underbygge og forny « den nordiske frihedslinie. Det gjaldt f.eks. i krisetiden i Sønderjylland: Netop fordi Flensborg Avis aldrig havde omtalt »alt dansk med ukritisk beundring, men søgt i dyb kærlighed til vort folk at arbejde med på det nye Danmark, har det været i stand til med vægt at tilbagevise den kritik, der i sin tøjlesløshed fik en brod imod Danmark ".

Ernst Christiansen sigtede her til krisebevægelserne inden for det sønderjyske landbrug, hvis tone navnlig i 1931-1932 havde været noget 
skinger. Ernst Christiansen udtrykte håb om støtte, om medhu, - og om »at det danske frihedssind ikke vil nægte os retten til en egen personlighed, retten til at føre vor kamp efter vor egen bedste overbevisning «.

Den slags bed imidlertid ikke på socialdemokrater, tvært imod: Det virkede stærkt ophidsende på gemytter som folketingsmand J.P. Nielsen og redaktør Frede Nielsen. Frede Nielsen forstod simpelthen ikke Ernst Christiansens holdning. Forskellen i opfattelsen af Tyskland var afgrundsdyb: For Ernst Christiansen var Tyskland først og fremmest Danmarks stærke nabo - uanset hvem, der regerede det, og Danmarks politik måtte forblive nogenlunde den samme. Det afgørende var hensynet til Danmarks interesser, som under de givne forhold krævede forståelse for sider af den herskende ideologi i Tyskland. For Frede Nielsen var der derimod tale om to helt forskellige Tysklande, der intet havde med hinanden at gøre - og som man følgelig også måtte forholde sig forskelligt til: Et demokratisk Tyskland kunne man opretholde venskabelige forbindelser til, hvorimod et totalitært Tyskland skulle vendes ryggen med foragt. Man var naturligvis fra socialdemokratisk side klar over, at Flensborg Avis - som udkommende inden for Det tredje Riges grænser - ikke ville slippe godt fra ligefrem at udslynge bandbuller imod nazismen, men man mente dog nok at kunne forlange en nogenlunde klar afstandtagen.

Flensborg Avis havde den 11. september 1935 kun nået at konstatere, at grænsegendarm Petersen i Sønderborg Socialdemokrat havde opfordret til at boykotte bladet. Det var imidlertid en sag, der havde rystet Ernst Christiansen så meget, at han dagen efter, den 12. september 1935, vendte tilbage til spørgsmålet $i$ en ledende artikel, som han gav titlen: I skal ikke blive glemt! Når et dansk blad i Nordslesvig [Sønderborg Socialdemokrat] kunne optage et indlæg med opfordring til at boykotte Flensborg Avis, skulle der nemlig "uden ønske om at forlænge et ordskifte, der bør sluttes hurtigst muligt«, siges et par rolige ord: "Hvis hvilket som helst blad i Kobenhavn eller Danmark over, Nordslesvig medindbefattet ... i en udenrigspolitisk oversigt havde gjort et enkelt fejlgreb, ville ikke en hund have gøet af det. Men det danske grænseblad skulle rigtignok have en anden behandling. Man mindes uvilkårligt det franske ordsprog: Hvor er det dyr dog ondskabsfuldt! Når man angriber det, forsvarer det sig oven i købet! «

Boykotningsforsøg ville stå i skærende modstrid med statsminister Neergaards ord, sagt på hele det danske folks vegne på Dybbøl i 
1920: „I skal ikke blive glemt!“ Enhver nationalt vågen dansk, der var ærekær på sit folks vegne, ville føle en boykot af Flensborg Avis som en dyb ydmygelse, erklærede Ernst Christiansen. Man ville tværtimod bedre kunne forstå det, hvis hver eneste grænsegendarm holdt - eller i det mindste læste - Flensborg Avis: »det er jo dog befolkningens blad, det gælder om, det blad, som har været banebrydende her, det blad, hvis gerning $i$ betydende grad har været en forudsætning for, at disse egne [hvor grænsegendarmerne patruljerede, RR] på grundlag af en afstemning kunne komme med til Danmark, det blad, som på udsat post stadig kaster sig i brechen for disse egne.« Det var et simpelt regnestykke: Selvom de folk, der byggede havdiget, havde en anden mening og ligesom andre mennesker kunne gribe fejl, ville man vel ikke standse tilførslen af jord og sten til diget og dermed lægge sin egen grund åben for stormfloden, mente Ernst Christiansen. Flensborg Avis var efter hans inderste overbevisning et sådant dige.

Ethvert barn burde vide, hvad kampen i Sønderjylland betød for Danmarks beståen, og de kæmpende havde krav på selvfølgelig folkelig solidaritet ved en udsat grænse, fortsatte Ernst Christiansen. Der stod nemlig meget på spil her, nemlig den danske friheds gode navn og rygte: »Man har villet bebrejde Flensborg Avis, at den ikke yderligere har skærpet modsætningerne ved grænsen, ved at slutte sig til de domme, der kun fandt noget frastødende og nedsættende i den nye tyske bevægelse og det nye Tyskland. Bag de stærke domme om det nye tyske livssyn har man hævdet, at der lå kærlighed til og stolthed over det danske folks udvikling til frihed, til den enkeltes umistelige ret til udfoldelse af sin egen personlighed. Det danske grænseblad har det samme ideal. Også vi har gennem menneskealdre ført en kamp for frihed og prist den som det kosteligste gode. Vi har særlig i de sidste år arbejdet på, at den danske og nordiske frihed igennem indre fornyelse, igennem frigørelse for brøst skulle trygges imod den skæbne, som er overgået folkestyret $i$ andre lande. Vi elsker den danske frihed af hele vort hjerte, men som danske gør vi så sandt også krav på at få part i den fra vort eget folks side.«

Folkestyret skulle med andre ord optage elementer af nationalsocialismen i sig for at overleve på længere sigt. Ernst Christiansen tænkte vel her først og fremmest på den kolossale energi, der blev sat ind for at samle nationen $i$ en fælles stræben fremad - eller $i$ hvert fald ét eller andet sted hen -, og som havde grebet størstedelen af det tyske folk. Det var tanker, der var ganske udbredte i Danmark i 1930'erne, 
ikke kun på den yderste højrefløj, hvor de egentlige nationale "genrejser «-bevægelser fandtes. De europæiske demokratier var i krise i 1930'erne, praktisk taget alle central-, øst- og sydeuropæiske lande var underlagt diktaturer, og selv ganske demokratisk indstillede mennesker talte om at "redde" det danske demokrati ved at skubbe uoverensstemmelserne mellem partierne - "partikævlet $\propto$ - til side og samle kræfterne om de presserende opgaver. Ernst Christiansen yndede at omtale den politiske udvikling i Tyskland efter 1933 som en "midtsamling " - venstrefløjspartierne var blevet opløst med magt, de borgerlige partier havde opløst sig selv, og Tyskland var endt med kun ét parti; dette havde samlet kræfterne, og han kunne jo konstatere, at det gik fremad i Tyskland. Noget tilsvarende så han gerne ske $i$ Danmark, dog skulle det jo helst ske på frivillig basis.

Sønderborg Socialdemokrat var som anført ikke indstillet på at lade Flensborg Avis forholde sig til nazismen som det passede den. Frede Nielsen tog atter ordet den 12. september 1935: „Vi har ikke været blinde for de vanskeligheder, bladet kom ind i efter nazi-sejren. Vi har været klar over, at bladet måtte være meget varsomt; men der er dog en grænse for alting. Og der er dog næppe nogen, som har dikteret bladet at prædike nazisme og anden tåbelighed for danske læsere«, skrev Frede Nielsen, og fortsatte: "Bladet har jo imidlertid - det ved alle, som følger det - den ene gang efter den anden skullet optræde med pegepinden, og det har elsket at stille sig i positur som det, der var i besiddelse af alverdens visdom og livserfaring. Dets nazikampagne var af en sådan art, at selv udpræget danske mænd vendte sig fra det. Flensborg Avis glemte nemlig én ting. Det taler om, at vi og andre skal tage hensyn til dets vanskelige kamp. Det skulle også tænke på, at vi og andre, som kæmpede netop for dansk og nordisk frihed og folkestyre, måtte føle os forrådt af Flensborg Avis netop i den periode, da stormen sydfra var allervoldsomst «.

Sønderborg Socialdemokrat havde fulgt en velovervejet forsoningsholdning over for det demokratiske Weimar-Tyskland med et socialdemokrati, der sammen med det danske ubetinget gik ind for grænsens bevarelse, men lige så selvfølgeligt havde man vendt sig imod det nazistiske Tyskland, »hvis hele lære måtte være alle nordiske mennesker så inderligt imod, og som betød en til tider ligefrem eksplosiv fare for grænsen «.

Det var efter Frede Nielsens mening direkte usmageligt, at avisen 
klamrede sig til sin fortid og endnu mere usmageligt, at det »krøb ind under kongeordet til sydslesvigerne: I skal ikke blive glemte. Tror bladet, at det er ensbetydende med syndforladelse til alle tider? « Flensborg Avis' selvgodhed trængte virkelig til kritik. Det var naturligvis trist, hvis Frede Nielsen havde "såret mimosen «, men det var der jo ikke noget at gøre ved; Sønderborg Socialdemokrat lagde ikke linien om og havde i sinde også i fremtiden af følge Flensborg Avis' journalistik og påtale udfordrende fejlgreb. »Så længe bladet kæmper for den fortvivlede ordning, at det med hel- og halvofficiel støtte skal udgå som almindeligt dagblad nord for grænsen og ofre de fleste af sine kræfter her, mens kampen syd på dog ellers skulle være mere end nok, så længe må det tage de skrammer, der følger med, og som det selv så stærkt er ude om.« Der var ikke megen medhu at finde i Sønderborg Socialdemokrat.

For Frede Nielsen var det nazismen, der truede grænsen, og derfor skulle den bekæmpes med alle til rådighed stående midler. For Ernst Christiansen så sagen anderledes ud. Han tog - lidt mere spids i tonen, men dog på trods af de prygl, Frede Nielsen delte ud, fortsat stilfærdig - til genmæle i Flensborg Avis den 13. september 1935: Flensborg Avis havde ikke "svigtet den danske frihedslinie, men den har gjort sit til at forebygge, at der på en tid, da der - efter det socialdemokratiske blads egne ord - var ligefrem eksplosiv fare for grænsen, hobedes endnu mere sprængstof sammen og så at sige blev gjort forsøg på at slynge tændte fakler ind i det«.

Socialdemokraterne havde ganske rigtigt søgt at fremme fred og forsoning og samarbejde med det tidligere demokratiske Tyskland, men arbejdet for fred og forsoning med det nye Tyskland kunne ikke opgives på en tid, da det var allermest tiltrængt. I virkeligheden havde den linie, som Flensborg Avis havde fulgt i forholdet mellem de to lande, været den, som statsministeren og udenrigsministeren gang efter gang havde understreget over for vildskud i den danske presse, mente Ernst Christiansen. Hvad Flensborg Avis havde tilladt sig ud over dette, var en påpegelse af, at en "ensidig forkastelse af alt i det nye Tyskland både er $i$ modstrid med kendsgerningerne og i modstrid med Danmarks tarv. Faren for dansk frihedssyn og folkestyre ville have været forsvindende, hvis det nye Tyskland var så sort, som man har malet det. En sandfærdig fremstilling vil snarere have den virkning, at det danske folk tager sig sammen for at værge sit folkestyre ved stadig mere fornyelse og udskillelse af brøst«. 
Flensborg Avis havde altså ikke prædiket nazisme, men derimod oplyst sagligt om det nye Tyskland - hvilket var noget ganske andet! Og det var først og fremmest sket for at redde folkestyret ved at forny det. Hvordan det skulle fornys og hvilke brøst, der var tale om, er dog ikke umiddelbart indlysende.

At Flensborg Avis m.h.t. indtagelsen af en forsigtig holdning over for Hitler-Tyskland var i større overensstemmelse med socialdemokraten Stauning end Sønderborg Socialdemokrat er utvivlsomt; dog byggede den danske regerings argumentation udelukkende på faren ved at tirre den store nabo - og ikke på forståelse for naboens samfundssystem.

\section{J.P. Nielsen truer Flensborg Avis på økonomien}

J.P. Nielsen havde endnu en del på hjerte. På trods af PaludanMüllers bøn om at forholde sig i ro, rykkede han den 14. september 1935 ud med et indlæg på ledende plads i Sønderborg Socialdemokrat. Han ville ikke tage til genmæle over for Nationaltidende/Dagens Nyheders "revolverjournalistik ", men ville dog gerne klarlægge sit forhold til Flensborg Avis. Det var tydeligvis et spørgsmål, der lå ham meget stærkt på sinde: Flensborg Avis havde forleden talt om sine "sande venner «, der blev hos det i tykt og tyndt. Dem havde J.P. Nielsen aldrig gjort fordring på at tilhøre, og det kunne bladet heller ikke ønske, thi det havde jo alle dage "skyet socialdemokrater som pesten «. Men hvor var bladets venner for tre år siden, da bladet var $\mathbf{i}$ økonomisk nød og bad om håndsrækning? Da glimrede Dagens Nyheder og mange flere ved deres fravær, hvorimod det var professor Ehlers og J.P. Nielsen selv, der pressede den "lede og forhadte socialist" Stauning til at tage sagen op og føre den igennem. Der var kun en eneste ven, der meldte sig, nemlig landstingsmand Hans Jefsen Christensen, "og han er jo som bekendt ikke helt ægte«. - Hans Jefsen Christensen havde i parentes bemærket både i grænsekampen og senere som formand for Skoleforeningen forholdt sig kritisk-positivt til det danske arbejde i Sydslesvig.

J.P. Nielsen fandt det "ganske ubegribeligt, at Flensborg Avis som organ for et lille land kunne give blot skin af et forsvar for Italiens handling; thi Danmark har kun for sin selvstændigheds skyld at håbe på rettens sejr«. For bladets egen skyld ville det være godt, om det snart fandt sine egne ben og lod storpolitikken og angrebene på dansk administration fare. Der kunne være mange grunde til, at det gik bladet økono- 


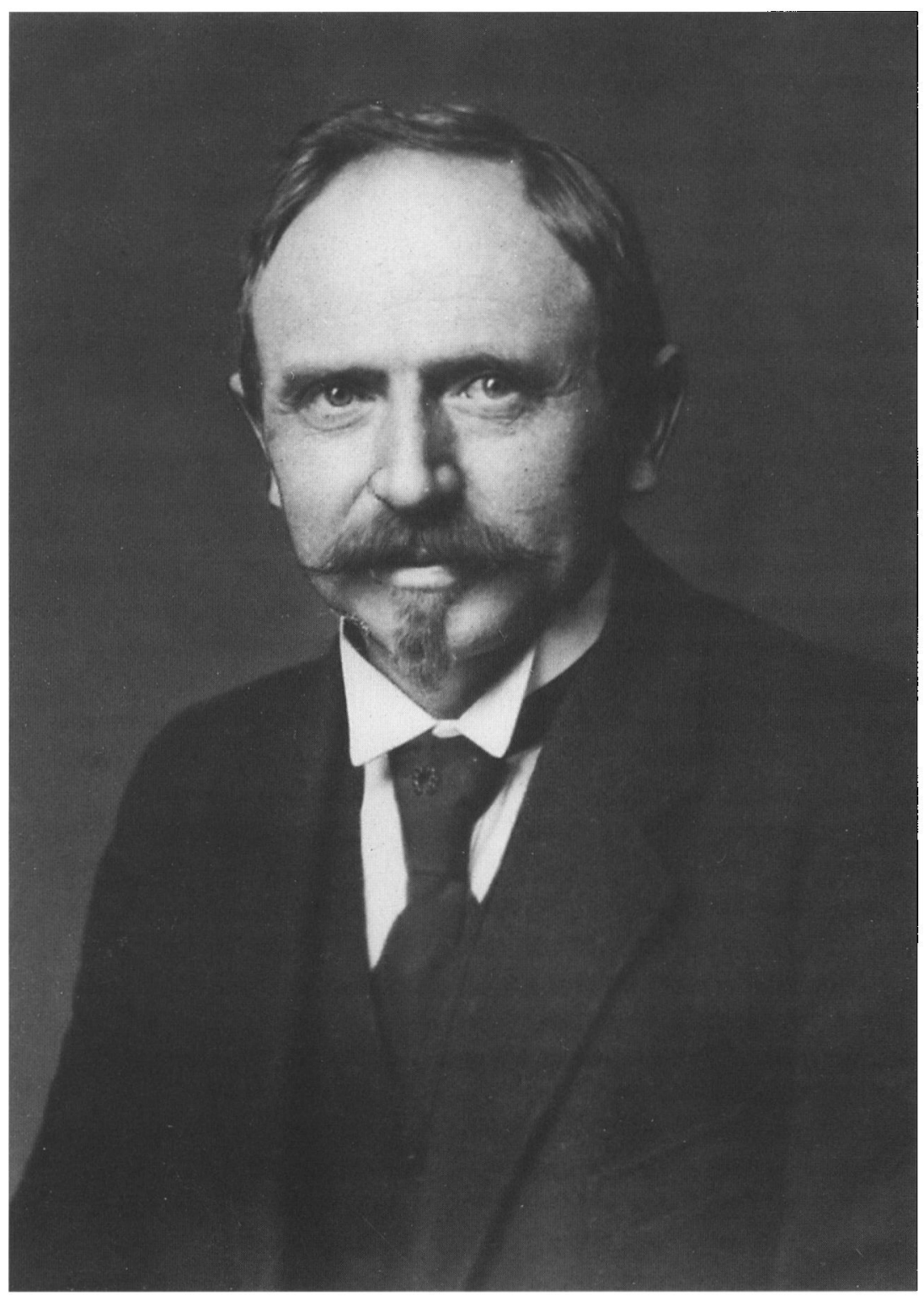

Jens Peter (I.P.) Nielsen (1873-1952). I 1920 blev han af Stauning udpeget som socialdemokratiets mand $i$ Sonderjylland. Folketingsmedlem 1920-1943 med bopæl $i$ Dynt fra 1924. I.P. Nielsen var en skarp modstander af nationalsocialismen og en temperamentsfuld debattør. Foto: Nordisk Pressefoto $i$ Dansk Centralbibliotek for Sydslesvig. 
misk dårligt; Flensborg Avis bebrejdede selv højlydt Danmark, at det ikke gav trygge og solide forhold at arbejde under. Men »det må dog være indlysende for enhver, at et blad kan ikke forlange støtte fra alle politiske retninger her i landet, når det stadig vil holde vejen åben som politisk organ. Flensborg Avis vil stadig være Flensborg Venstreblad med forbindelse til det noble organ Dagens Nyheder i Kobenhavn. Det må Flensborg Avis naturligvis gerne, men derved har bladet også frigjort os andre for medvirkning; thi vi vil naturligvis ikke være med til at bevilge penge for at få vore anskuelser bekæmpet.«

Dette var en trussel, der ville noget, for uden økonomisk støtte fra et bredt flertal blandt de danske partier ville det snart være nat med Flensborg Avis. Siden kronedevalueringen i 1931, der med ét slag ændrede Flensborg Avis fra en - meget beskeden - overskudsforretning til en dundrende underskudsforretning, havde avisen været dybt afhængig af tilskud fra den danske stat - den såkaldte valutaudligning. Med størsteparten af sine indtægter i svækkede kroner og størsteparten af sine udgifter i stærke rigsmark, var Flensborg Avis dømt til undergang, hvis den danske regering lukkede pengepungen. Og netop J.P. Nielsen var det regeringsbærende socialdemokratis repræsentant i det folketingsudvalg, der bevilgede støtten.

Om bladets linie fortsatte J.P. Nielsen: »I 1920 var det således, at hvis nogen blot sagde et venligt ord om det slagne Tyskland eller søgte at række det en hjælpende hånd, således som vi gjorde det overfor tyske børn, så var vi skidtsaker og blev stillet $i$ bladets gabestok. Hvis vi vovede at kritisere entente-landene, eller deres famøse Versailles-traktat, så råbte bladet landsforrædere efter os. Nu er det omvendt. Nu hæves det nazistiske Tyskland til skyerne og der uddeles spark i Verdens Gang til England og Frankrig«.

Selvom J.P. Nielsen slog med en noget for stor hammer og på flere punkter var urimelig i sine påstande, er der dog så megen sandhed i dem, at Flensborg Avis faktisk havde gjort en bemærkelsesværdig kovending i forhold til Tyskland. I første halvdel af 1920'erne havde man i forlængelse af grænsekampen fort en overordentlig skarp kurs over for såvel Tyskland som de danske partier, der havde været bladets modstandere i grænsekampen. Der blev først i 1920'erne stadig kæmpet offensivt for at medvirke til en løsrivelse af Sydslesvig fra Tyskland, og den sammensparede bitterhed over navnlig de radikales og socialdemokraternes "svigt « 1920 var dagligt kommet til udtryk $i$ avisen. I sidste halvdel af 1920'erne var der imidlertid sket en æn- 
dring: Man havde indstillet sig på, at en genforening af Sydslesvig havde lange udsigter, og at det gjaldt om tålmodigt at afvente historiens gang. I mellemtiden måtte alle kræfter i Danmark samles, så man stod samlet og forberedt, når det rette øjeblik indtraf. En forsoningsproces med de tidligere politiske modstandere i Danmark havde i lobet af 1920 'ernes sidste halvdel haft god fremgang. I mellemtiden skulle nationalitetskampen føres med kulturelle midler efter løsenet Front og Bro, hvilket indebar en imødekommende indstilling over for Tyskland. Denne imødekommende indstilling var blevet stadigt mere tydelig i årene fra 1929-1930 og fremefter - og den blev fortsat også efter Hitlers magtovertagelse i 1933. J.P. Nielsens fortolkning af denne udvikling i Flensborg Avis' linie var spidset til i urimelig grad, og han overså fuldstændig, at en helt tilsvarende udvikling havde fundet sted $i$ avisens forhold til hans eget parti.

Socialdemokraterne havde i øvrigt også foretaget en kovending over for Tyskland efter Hitlers magtovertagelse - men med modsat fortegn: Fra venligsindet samarbejde med Weimar-Tyskland til skarp afvisning af Hitler-Tyskland.

Flensborg Avis havde forsvaret sig med, at havde det fulgt en anden linje, levede det ikke mere. "Jeg synes dette trænger til en forklaring; thi alt for hastige til at dreje halsen om på Flensborg Avis ville tyske myndigheder næppe være, særlig når de ser, hvorledes deres eget kære barn i Aabenraa [Nordschleswigsche Zeitung, RR] boltrer sig. Og særlig stor betydning for danskheden kan bladet ikke have, hvis hr. overborgmester Sievers [i Flensborg, RR] foruden at kommandere sine nazister på denne side af grænsen også skal være toneangivende for bladet. (...) Vi fra vor side vil arbejde for og støtte et mindretalsblad, der er talerør for det danske mindretal og dettes krav syd for grænsen, men ser bort fra indblanding i vore politiske forhold. Vi ønsker ikke på nogen måde at fortrædige Flensborg Avis, heller ikke på nogen måde at beskære dets frihed. Det må for os være det, som det er: Flensborg Venstreblad; men så er det eneste naturlige, at det søger støtte hos venstrepartiet. Sådan ville vi gøre hos vort parti, hvis vort blad trængte til støtte, eller også kan bladet henvende sig til sine sande venner ved Dagens Nyheder."

J.P. Nielsens uforsonlighed over for Flensborg Avis er meget påfaldende; her var tydeligvis tale om noget i retning af en "sidste advarsel« til avisen.

Ernst Christiansen svarede kort den 17. september 1935, at J.P. Niel- 
sens artikel havde »... gjort os ondt, ikke kun på bladets, men på vort folks vegne. Det må være tilstrækkeligt at sige, om noget tilsvarende er hændt eller kan tænkes på tysk side, om det tyske grænseblad, der vel ikke skal vurderes højere end Flensborg Avis, gang efter gang bliver omtalt nedsættende af egne landsmænd, om det [det tyske blad] ikke tværtimod som en selvfølge og uden hvert øjeblik at skulle stå skoleret $\mathrm{i}$ offentligheden får støtte fra alle tyske hold. Et spørgsmål er, hvad der er tjenligt for det danske folks sag ved Danmarks grænse, et andet spørgsmål hvad simpel værdighed kræver. På begge disse spørgsmål må der efter vor mening gives det samme skarpe svar. De ydmygelser vi møder fra modpartens side i den nationale kamp, synes os for intet at regne mod dem, der bydes os af vor egne."

Der er ingen tvivl om, at Ernst Christiansen blev dybt berørt over J.P. Nielsens angreb. Han har formentlig drøftet sagen med Kaj Munk, der i de samme dage gæstede Flensborg for at læse sit nyeste stykke Kærlighed op på Duborgskolen. ${ }^{29}$ Også Kaj Munk kendte til at føle sig miskendt, og han skrev trøstende til Ernst Christiansen den 20. september 1935: »Det er undertiden godt at huske sig på, at man skal gøre sit arbejde ikke for danskerne, men for Danmark. ${ }^{30}$

Dette synspunkt har Ernst Christiansen, der selv nærede idealiserede forestillinger om Danmark, med sikkerhed kunnet tilslutte sig. For en socialdemokrat ville en sådan udtalelse formentlig være vanskeligt forståelig; her hyldede man ikke folket for Danmark, men derimod Danmark for folket.

\section{Ernst Christiansen kontakter Stauning}

Sagen begyndte nu at gå Ernst Christiansen på nerverne. ${ }^{31}$ Truslen om at smække statens pengekasse i var meget alvorlig, for dette ville medføre den visse død for Flensborg Avis, der umuligt kunne klare sig uden de statslige tilskud. ${ }^{32}$ Ernst Christiansen så ingen anden udvej end at henvende sig direkte til Stauning for at afbøde eventuelle økonomiske konsekvenser af J.P. Nielsens anklager. Lige som det havde været tilfældet med Paludan-Müller, stod den ulyksalige abessinske sags anden parthaver nu også i en situation, hvor han var nødt til at forklare sig for regeringen.

Den 16. september 1935 sendte Ernst Christiansen Stauning et eksemplar af Sønderborg Socialdemokrat med J.P. Nielsens artikel og tilføjede, at han ville bortse fra en egentlig imødegåelse og kun nævne to 
ting, nemlig at det i sagen mod grænsegendarmeriets chef havde drejet sig om en betragtning i bladets udenrigspolitiske rubrik, som han ikke havde set før bladets offentliggørelse, som han straks havde påtalt og som bladet flere gange offentligt havde taget afstand fra, og "med hensyn til hr. J.P. Nielsens forsøg på at stemple Flensborg Avis som Flensborg Venstreblad tør jeg påstå, at J.P. Nielsen ved, at det er fuldkommen uholdbar påstand, fordi bladet på det alvorligste bestræber sig for at holde sig uden for partierne og ved valgene har givet ordet frit uden selv at tage standpunkt «. J.P. Nielsen havde igennem årene mange gange "fremsat stærke udfald imod Flensborg Avis«, fortsatte Ernst Christiansen. "Vi har altid søgt at svare roligt og sagligt og om muligt at overbevise ham. Og det er tilsyneladende hver gang i nogen måde lykkedes for en tid. I det sidste år har det harmet os meget, når han og hans blad, skønt de ved, at det udelukkende er den danske krone-nedskæring, der har voldt vore vanskeligheder, har hånet os i offentligheden med, at vi gik med klingpungen «, klagede Ernst Christiansen, og fortsatte: »Når J.P. Nielsen, som i sin tale forleden i Brunsnæs og nu i den sidste artikel, bredt diskuterer i offentligheden ikke alene Flensborg Avis' påståede fejl, hvad ingen vil hindre ham i, men også bladets tilskud og statens forhold hertil, så, synes det mig i den grad skadeligt, ikke kun for bladet, der står her på en meget udsat post, men også for de danske interesser i grænselandet og for de danske statsinteresser i forhold til Tyskland, at det ikke bør fortsættes.« Ernst Christiansen sluttede sit brev med at forsikre, at det ikke var »meningen, at dette skal være et klagebrev, det tager kun sigte på fremtiden, og jeg vil gerne henstille til den højtærede statsminister, om det ikke er ønskeligt og muligt at få folketingsmand J.P. Nielsen til at tage det bydende nødvendige folkepolitiske og statspolitiske hensyn ikke at behandle disse ting offentligt. « $^{33}$

Dette sidste blev i de samme dage understreget af Nordschleswigsche Zeitung, det tyske mindretals på dette tidspunkt gennem-nazificerede avis, der fandt mange passager i debatten værd at citere - og navnlig noterede sig, at det var Stauning og socialdemokraterne, der tre år tidligere havde reddet Flensborg Avis. ${ }^{34}$ Det var jo rart at vide, for derved kunne man i sin polemik imod Flensborg Avis indirekte gøre den danske regering ansvarlig for udtalelser, fremsat af Flensborg Avis om f.eks. Tyskland eller det tyske mindretal. Eller man kunne beskylde Flensborg Avis for at være i lommen på socialdemokraterne - eller "marxisterne « som de hed i nationalsocialistisk terminologi, hvilket 
heller ikke var at foragte. Den slags var - som Flensborg Avis den 19. september 1935 udtrykte det: »Mad for Mons«.

\section{Det sidste ord}

Ernst Christiansen fik nu alligevel det sidste ord i denne omgang. Den 25. september $1935 \mathrm{skrev}$ han i en 31/2 spalter lang leder bl.a., at der naturligt nok kunne være uenighed om, hvordan man skulle optræde over for nabofolket, "særlig efter at han har fået en ny, hidtil ukendt indstilling. Når vi siger at denne er mere fremmed end nogen sinde, er det dog en forslidt talemåde. Kunne den blive mere fremmed end dengang, da "Blod og Jern ", da tvangstægt og fratagelse af forældreretten var løsnet over os? «

Ernst Christiansen gav her meget tydeligt udtryk for, at han endnu ikke havde forstået den afgrundsdybe forskel, der bestod imellem det Wilhelminske og det nationalsocialistiske Tyskland.

I synet på Tyskland gjaldt efter Ernst Christiansens mening ikke noget enten-eller men derimod et både-og. "Vi må være klar over, hvad det er, vi vil. Ønsker vi størst muligt fjendskab? En stadig voldsommere gensidig ophidsning, oprustningen lige for en krig? Er det ikke vort mål at hævde vort eget i sund vækst og samtidig om muligt trygge det danske lands og folks grænse ved at formindske den spænding, de ophobninger og sprængstof, som findes? Skal dette sidste ikke være vort vigtigste bidrag til fremme af verdensfreden, til at forebygge nye krigsulykker? « Opgaven var et både-og: "utrætteligt at modvirke mistænksomheden og føre bevis for, hvor tillidvækkende vore hensigter er. Vort mål må være mere og mere at få alle vore egne på post og i arbejde uden at skærpe modsætningerne udadtil.

$\mathrm{Ja}$, og hindre vore unge $\mathrm{i}$ at blive nationalsocialister! indvendes der. Ja, naturligvis, vi ønsker, at vore unge skal fortsætte dansk og nordisk, ikke tysk udvikling. Men ville vi opnå det, såfremt vi overfor de unge ikke ville lade kendsgerningerne tale deres dog ret tydelige sprog, men malede sort alt, hvad der fandtes hos den anden part? Ville de unge ikke hurtigt selv opdage, hvor det ikke stemte og så blive mistænksomme? Må vejen ikke være den at få vort eget frihedssyn levende og stærkt frem i den unge slægts bevidsthed og søge at få den til at fatte til liv og sjæl, hvad frihed vil sige, og at gå foran i et arbejde for at fjerne de brøst, der også findes i vort eget folks hævdelse af friheden? «

Tyskland havde efter Ernst Christiansens mening lige siden 1933 


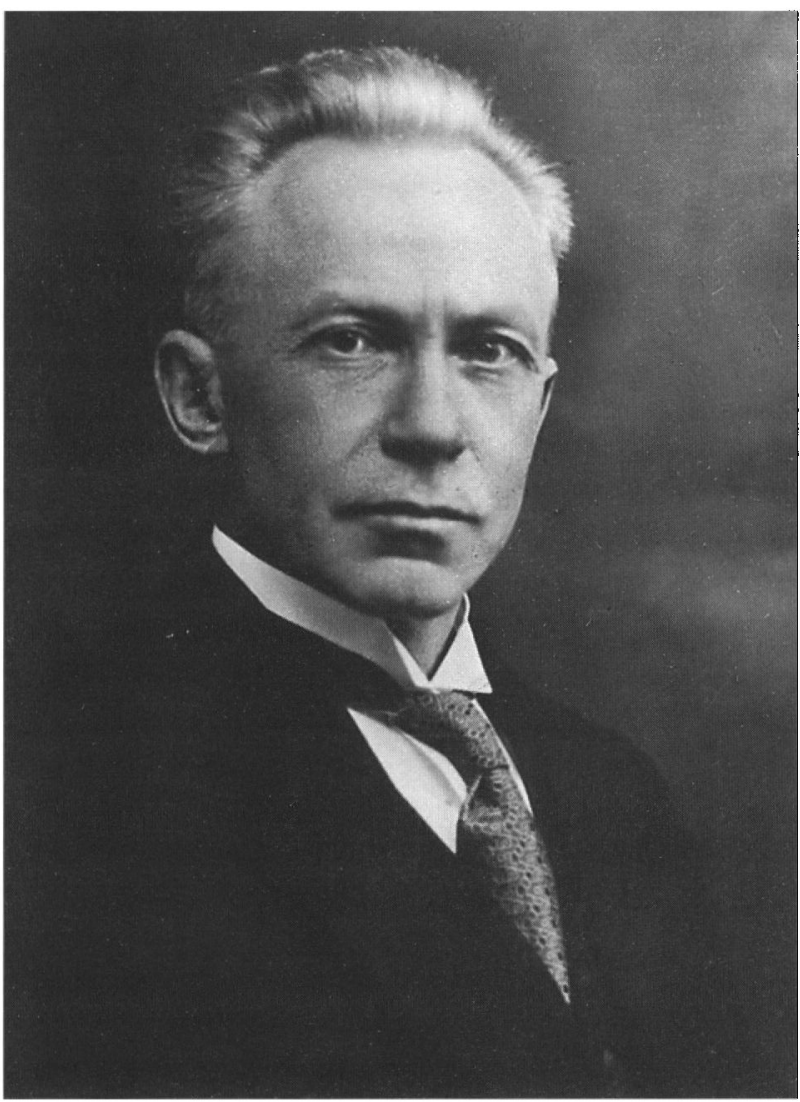

Ernst Christiansen (1877-1941), chefredaktor for Flensborg Avis fra 1906. Under grænsekampen 1918-20 var han forkæmper for en grænse ved Danevirke, og efter afgrrelsen i 1920 mindretallets førende mand. Omkring 1930 formulerede han mindretallets rolle som danskhedens "front og bro" til Tyskland; et synspunkt, som medførte oget forståelse for udviklingen $i$ Tyskland. Foto $i$ Dansk Centralbibliotek for Sydslesvig.

arbejdet på at tilvejebringe et godt naboforhold til Danmark og Norden. "Men samtidig har det nye Tyskland i højeste grad sat hele det tyske folks nationale midtsamling i spidsen og mere end nogen sinde tidligere søgt at opnå, at ethvert barn og enhver voksen i landet føler sig forpligtet til at stå last og brast med tyskerne uden for grænserne. Og dette er ikke alt. Rigtignok er alt for ivrige ordføreres lyst til at tale om grænseflytning blevet dæmpet, rigtignok har det nye Tysklands ledelse selv forbeholdt sig enhver bestemmelse om denne side af sagen, har Hitler i sin bog stemplet kravene om at få grænserne fra 1914 tilbage som politisk vanvid og har hans stedfortræder Hess direkte i en offentlig erklæring nævnt Danmark blandt de små nabolande, overfor hvem Tyskland ingen tanke har om erobring og vold, men der er samtidig ikke fra tysk side lagt skjul på, at det nye 
Tyskland lige så lidt som det gamle anser afgørelsen fra 1920 for endelig." Dette fremgik også af den tyske indsats ved grænsen; der var endog ligefrem blevet udtalt, at man forventede en ny afstemning med efterfølgende grænseflytning, således at »hverken Danmark eller det gamle Slesvig-Holsten bliver tilfreds «.

Dette måtte tages til efterretning, men var dog stadig et fremskridt i forhold til dengang, da mange tyskere kun drømte om den næste krig. Men den tyske kraftanspændelse ved grænsen måtte imødegås af en tilsvarende dansk, og »hvor det gælder indre danske modsætninger, indre dansk kritik, må der i grænselandet tages et vist hensyn både til fælles ære og til fælles tarv, således at vi vogter os for, omend kun ufrivilligt, at gå den nationale modparts ærinde“.

Hvis Danmark mistede Nordslesvig igen, "ville det være vor egen skyld. Vi ønsker ikke, det skal ske. Velan, drager vi følgeslutningerne af vor erkendelse og vor vilje, så sker det ikke. Men den første og sidste følgeslutning er en lysvågen og offervillig danskhed, en ungdom, der kan begejstres. Nordslesvigs ungdom, det danske folks ungdom må mere og mere komme til at indse, som noget, der svier ind i dens inderste sjæl, at det gælder liv og død i Sønderjylland for vort folk. Ud af denne verden vil ikke gro forsagthed og fejhed, men den nordiske ildhu, der med et kvad på læben springer igennem bålet. En sådan ildhu vil også til sidst tiltvinge sig respekt for dansk ret $i$ Sønderjylland i det tyske folks sind."

Ernst Christiansen havde ikke flyttet sig mange centimeter i sin opfattelse af Tyskland, men Sønderborg Socialdemokrat undlod at kommentere sagen yderligere. Muligvis har man fået et vink fra Stauning om, at den affære var bedst tjent med at ebbe ud, men snarere har det tilstundende folketingsvalg lagt beslag på alle bladets kræfter. Da september 1935 gik til ende, var ordskiftet forbi.

Under hele den ophedede debat i september måned havde PaludanMüller holdt sig i ro - når bortses fra hans indgriben m.h.t. gendarm Petersens uheldige læserbrev. Han var sendt på tvungen orlov, og han var rejst bort fra Sønderjylland.

\section{Paludan-Müller genindtræder i tjenesten}

Den 3. oktober 1935 angreb italienske tropper Abessinien fra kolonierne Eritrea i nord og Somaliland i øst. Efter få dage erklærede Folkefor- 
bundet Italien som aggressor. Folkeforbundet nedsatte et udvalg, der skulle planlægge sanktionerne mod Italien.

Flensborg Avis forsøgte i sin dækning af krigen at dele sol og vind lige, idet man citerede nogenlunde ligeligt fra italienske, tyske, engelske, franske og amerikanske aviser. På lederplads var der tavshed. I én af de små sentenser, der er typiske for Flensborg Avis i Ernst Christiansens tid, hed det den 4. oktober 1935: „Terningerne er kastet, krigen er i fuld gang, skønt den er varslet for år og dag siden og der lige så længe er arbejdet på at forebygge den. Vi ser stenen rulle nede i Afrika, men ved ikke, hvilket sneskred den kan udløse. Med spænding venter verden i første omgang på, hvad Folkeforbundet, hvad England nu vil foretage sig".

Det var fortsat freden i Europa, der var Flensborg Avis' største bekymring.

Krigen i Abessinien berørte Paludan-Müller dybt. Under krigen skrev han digtet

\section{Et folk $i$ nød}

Fra de vilde tigres bjerge / og til Rudolfsøens bredder / kæmped morke mænd for frihed / $i$ det sidste oldtidsrige. / Glemmes skal ej disse helte: / Mulageta, Kassa, Imru / Seyum, Nazibu, og Vehib / og den trofaste Ras Desta, / som i håbløs kamp omringet / for sin fjerne kejser døde. / Hil dig, simple, vilde kriger, / som med knuste lemmer stønned, / uden hjælp $i$ øde kløfter / til du under nattens stjerner / for hyænens bid forblødte. / Hil dig, ædle, tapre kejser, / som på dine spinkle skuldre / bar dit kæmperiges byrde, / på den hvide mand du stoled, / skamfuld bøjer jeg mit hoved, / thi vi sveg dig fejgt $i$ nøden, / og de dræbte småbørns klage / vil vi høre alle dage. ${ }^{35}$

Resultatet af Folkeforbundets sanktionsudvalgs forhandlinger blev en international finans- og handelsboykot, der dog undtog så vigtige varer som olie, kul og jern. Sanktionerne trådte i kraft 18. november 1935. Paludan-Müller genindtrådte i tjenesten som chef for grænsegendarmeriet den 14. november 1935 - lige netop tids nok til at være med til at effektuere indførselsforbudet imod italienske varer som følge af sanktionerne. 


\section{LITTERATUR OG KILDER}

Rigsarkivet (RA): Finansministeriets arkiv. 38 nr. C 1416 Dept. f. Told og Forbrugsafgifter. C-sager. Paludan-Müller, Oberst, R. af Dbg. Dbmd. Chef for Grænsegendarmeriet.

Landsarkivet for Sonderjylland (LA): $P$ 106, Ernst Christiansens arkiv. Grænsegendarmeriets arkiv.

Arkivet ved Dansk Centralbibliotek for Sydslesvig (DCB): E1, Flensborg Avis' arkiv.

Dagblade: Flensborg Avis, Hejmdal, Sønderborg Socialdemokrat, Nationaltidende/Dagens Nyheder samt en række andre dagblade (se noterne) august-oktober 1935 .

Lars Bjørneboe: Ingen kender dagen. Grænsegendarmeriet under krig og besættelse 1940-1945. Kobenhavn, 1970.

Nic. Blædel: Forbrydelse og Dumhed. København, 1945.

R. Kreth \& R. Rasmussen: En mønsteravis og en propagandarejse. Glimt af danske og tyske forsøg på at påvirke dansk presse. I tradition og kaos - festskrift til Henning Poulsen. Aarhus, 2000.

R. Kreth: Pilestræde under pres. Kobenhavn, 1998.

Carsten R. Mogensen: Dansk i hagekorsets skygge. Flensborg, 1981.

J.P. Noack: Det danske mindretal 19201945. Aabenraa, 1989.

Sven Sabroe: Ene Mand mod Gestapo. Oberst Paludan-Müllers heltemodige kamp i Graasten. Kabenhavn, 1945.

\section{NOTER}

1. Sven Sabroe: Ene mand mod Gestapo. Kobenhavn, 1945.

2. RA, $38 \mathrm{nr}$. C 1416. Regimentets forholdsattest af 20.5. 1932. Her bragt efter citat $i$ kontorchef Michael Kofoeds anbefaling til finansministeren 4.1.1933.

3. Se f.eks. A.J.P. Taylor: Årsagerne til 2. verdenskrig, Viborg 1978 (2. udg.) s. 93-106 og Nic. Blædel: Forbrydelse og Dumhed. Kobenhavn, 1946 s. 273-289.

4. DCB, E1-6. Paludan-Müller til Flensborg Avis 31.8.1935; Ernst Christiansen-notat.
5. LA, P106-32. Ernst Christiansens dagbøger 2.9.1935.

6. DCB, E1-6. Ernst Christiansen til Paludan-Müller 2.9.1935. LA, Græensegendarmeriets arkiv pk. 267, diverse A-sager 1935-1937: Samme.

7. LA, P106-32 Ernst Christiansens dagbøger 3.9.1935. Her som i andre citater fra dagbøgerne er Ernst Christiansens stenografiske forkortelser så vidt muligt oplost $i$ hele ord.

8. Holdningen præciseres i Flensborg Avis den 15.9.1935.

9. DCB, E1-6. P. Grau til Paludan-Müller 4.9.1935 (afskrift), E. Møren til Flensborg Avis 4.9.1935, Chr. Refslund; Ida Schrader til Flensborg Avis 5.9.1935, M. Schiødte til Ernst Christiansen 6.9.1935 og dennes svar 7.9.1935 og førstnæuntes gensvar 10.9.1935.

10. DCB, E1-6. Ernst Christiansen til E. Jensen 12.9.1935 og dennes svar 22.9.1935.

11. LA, P106-32. Ernst Christiansens dagbøger 4.9.-6.9.1935.

12. DCB, E1-6. Ernst Christiansen til Paludan-Müller 5.9. og 11.9.1935; dennes svar 5.9., 9.9. og 11.9.1935 samt genbestilling af abonnementet 5.9.1935.

13. Ifølge Sabroe, 1945 s. $67 \mathrm{f}$, gav Paludan-Müllers artikel "anledning til et formeligt raseri i det italienske gesandtskab i København, der straks gjorde forestillinger overfor regeringen. Grænsegendarmeriet sorterer under finansministeriet, og italienerne krævede at Paludan-Müller straks blev afskediget. Man traf for at tilfredsstille italienerne en meget alvorlig afgørelse i sagen", nemlig foreløbig orlov og en bøde på en halv måneds lon.

Det er imidlertid tvivlsomt, om der nogensinde kom til at foreligge en officiel klage fra italiensk side. Det umuliggør naturligvis ikke, at man fra det italienske gesandtskab mundtligt kan have gjort forestillinger overfor det danske udenrigsministerium, hvor man har lovet at gore noget ved sagen - hvilket tilsyneladende har tilfredsstillet italienerne. 
14. RA, Finansministeriet, 38 nr. C 1416, Notat i Departementet for Told og Forbrugsafgifter dateret 5.9.1935.

15. RA, Finansministeriet, $38 \mathrm{nr}$. C 1416. Skrivelse fra Finansministeriet af 6.9.1935. Offentliggjort i Hejmdal 6.9. og 7.9.1935.

16. RA, Finansministeriet, $38 \mathrm{nr}$. C 1416. Udkast til redegorelse i Departementet for Told og Forbrugsafgifter, udateret, men formentlig 11.8.1943 eller nærmest følgende dage.

17. F.eks. Aalborg Stiftstidende 5.9.1935.

18. Modersmaalet 5.9. og 6.9.1935.

19. Ifølge Sabroe s. $67 \mathrm{ff}$ "strømmede det ind « med indlæg til Hejmdal imod Flensborg Avis. Dette har dog ikke kunnet konstateres.

20. Nationaltidende/Dagens Nyheder 6.9.1935, 7.9.1935. Kolding Folkeblad 7.9.1935.

21. F.eks. Lolland-Falsters Folkeblad 9.9.1935 og Kolding Folkeblad 7.9.1935.

22. RA, Finansministeriet, 38 nr. C 1416. J.P. Nielsen til H. P. Hansen 8.9. 1935.

23. Det har givetvis vakt irritation hos socialdemokraterne, at de måtte overlade det rene standpunkt til kommunisterne, der nok vidste at fiske i rorte vande. Se f.eks. Arbejderbladet den 14.9. og 18.9.1935.

24. Socialdemokraten 12.9.1935. Senderborg Socialdemokrat 12.9.1935. Nationaltidende/Dagens Nyheder 13.9.1935. Sonderborg Socialdemokrat 16.9 .1935 meddeler, at Franz von Jessen personligt har skrevet og undskyldt for sin leder mod I.P. Nielsen. Pă DN havde de undersøgt sagen, men ikke fået den opklaret. Deres Aabenraa-korrespondent svor på at have anført, at der var tale om en indsendt artikel og han, der modtog telegrammet $i$ den anden ende pr. telefon, at han havde gengivet telefonsamtalen ordret.

25. RA, Finansministeriet, 38 nr. C 1416. Paludan-Müller til Finansministeriet 11.6.1935 med bilag: Ernst Christiansen til Paludan-Müller 11.9.1935.

26. RA, Finansministeriet, $38 \mathrm{nr}$. C 1416. Paludan-Müller til Finansministeriet 11.9.1935 med bilag: Ernst Christiansen til Paludan-Müller 11.9.1935.

27. Se f.eks. Vejle Amts Folkeblad 13.9.1935 og Aalborg Stiftstidende 14.9.1935.

28. Rasmus Kreth: Pilestræde under pres. Kobenhavn, 1998. Rasmus Kreth og René Rasmussen: En mønsteravis og en propagandarejse, $i: " I$ tradition og kaos. Festskrift til Henning Poulsen«, Århus, 2000.

29. René Rasmussen: „Kaj Munk og Flensborg Avis". Kronikker i Flensborg Avis den 27. og 28.10.1998.

30. LA, P106-23. Kaj Munk til Ernst Christiansen 20.9.1935.

31. LA, P106-18. Ernst Christiansen til H. P. Hansen 27.9.1935.

32. DCB, E1-6. Ernst Christiansen til Hans Jefsen Christensen 21.9.1935.

33. DCB, E1-6. Ernst Christiansen til Th. Stauning 16.9.1935.

34. F.eks. Nordschleswigsche Zeitung 13.9.1935 og 17.9.1935.

35. Sabroe, 1945, s. $68 \mathrm{f}$. 